\title{
Aspectos históricos e epistemológicos da Ciência da Religião no Brasil: Um estudo de caso
}

\author{
Historical and Epistemological Aspects of the Science of Religion in Brazil: A \\ case study
}

\begin{abstract}
Este artigo se propõe a analisar os três projetos de graduação elaborados no decorrer da história do departamento de $\mathrm{C}$. da Religião da Universidade Federal de Juiz de Fora. A primeira proposta foi elaborada em 1971. Em 1980, há tentativa de reestruturação mais profunda. Na década de 1990, ocorre a proposição de um curso de especialização tendo em vista a formulação de uma futura graduação. $\mathrm{E}$, por fim, em 2011 há um novo projeto pedagógico, que atualmente se encontra em andamento. Com intuito de se evitar uma abordagem histórica puramente descritiva e investir numa aproximação reflexiva, uma pergunta nos guiará: qual a concepção de ciência da religião subjacente a cada projeto pedagógico? No caso do curso da UFJF não somente houve alternância quanto ao nome (primeiramente, Ciências das Religiões depois Ciência das Religiões e, por fim, Ciência da Religião), mas também quanto às concepções que os projetos pedagógicos expressam. Parte-se de uma vinculação mais forte com a teologia, passando por uma aproximação com as ciências sociais e, chegando-se à ênfase nas diversas tradições religiosas e discussões teóricometodológicas.
\end{abstract}

Palavras-chave: Ciência da Religião, UFJF, epistemologia, aspectos históricos.

ABSTRACT

This article proposes to analyze the three undergraduate projects elaborated in the course of the history of the Department of Religion of the Federal University of Juiz de Fora. The first proposal was drawn up in 1971. In 1980, there was an attempt for a deeper restructuring. In the 1990s, there is the proposal of a specialization course in order to formulate a future graduation. And finally, in 2011 there was a new pedagogical project, which is currently underway. In order to avoid a purely factual historical approach and to invest in a reflexive one, a question will guide us: what is the conception of the science of religion that underlies each pedagogical project? In the case of the UFJF course, there was not only a change of name (firstly, Sciences of Religions, then Science of Religions and, finally, Science of Religion), but also with regard to the conceptions that pedagogical projects express. It begins with a stronger connection with theology, going to an approximation with the social sciences, and more recently we observe an emphasis on the different religious traditions and theoretical-methodological discussions.

1 Doutor em Ciências da Religião pela UMESP, Doutor em Filosofia pela USP e Professor Associado do Departamento de Ciência da Religião da Universidade Federal de Juiz de Fora. Contato: fredericopieper@gmail.com . Submetido em 24/08/2018; aceito em 23/04/2019. 
Keywords: Science of religion, UFJF, epistemology, historical aspects.

É possível discutir epistemologia de determinado campo do saber de maneira abstrata, definindo conceitos, delimitando âmbitos de abordagem para indicar como esse campo do saber deveria ser. Este modo de se tratar o tema tem sua importância e lugar. Por outro lado, pode-se interpelar essas mesmas temáticas a partir da concretude histórica. Essa aproximação se torna relevante por não termos o hábito de fazer história dos nossos campos, especialmente no âmbito da Ciência da Religião.Julgamos que o presente nos desafia com indagações mais prementes, não restando tempo e nem energia para olhar aquilo que já foi feito, tentando compreender as escolhas daqueles que nos antecederam e como elas ainda nos afetam. Além disso, há um aspecto peculiar dessa área. O veredito que Joachim Wach emitia em 1924 parece ser válido para nosso contexto. Do ponto de vista prático, o fato da área se constituir por especialistas oriundos de diversas áreas das ciências humanas se mostrou positivo e construtivo no estudo empírico da religião. No entanto, isso acabou sendo menos favorável quando se trata da reflexão teórica. Há a tendência desses pesquisadores em se manterem alinhados à área de origem, gerando pouco interesse em reflexões mais integradoras ou epistemológicas. Isso, em parte, explicaria a constatação de que a Ciência da Religião se encontra bem atrás de outros campos do saber nesse quesito. ${ }^{2}$

Portanto, voltar o olhar para o passado é perceber continuidades e rupturas que apontam possibilidades para o futuro. Aliás, no fundo, nosso interesse pelo passado é sempre motivado por perguntas do presente.Especialmente, nesse caso em que o autor vivenciou apenas uma parte desse processo histórico. $O$ acesso a esse passado é mediado por fontes disponíveis ${ }^{3}$. Quando nos voltamos para os vestígios que o passado nos legou por meio dos documentos, na verdade, queremos saber um pouco mais sobre nós mesmos, vendo nas soluções passadas o que elas abrem de possibilidades para problemas atuais.

Nessa direção, este artigo pretende analisar as propostas de cursos de graduação feitas no âmbito do Depto. de C. da Religião da UFJF. A intenção é perceber como as demandas históricas se articulam com reflexões epistemológicas. As relações que se estabelecem aqui são múltiplas. Se de um lado, concepções de C. da Religião são moldadas pelas contingências históricas, do mesmo modo as elaborações dos projetos pedagógicos espelham entendimentos do que em cada momento se entende ser a tarefa de uma ciência da religião. E esses entendimentos, por sua vez,engendram práticas.

Mas, o estudo da trajetória de um caso particular poderia ter interesse mais amplo? Penso que sim. Afinal, muitos dos desafios, problemas e proposições que se percebem nos projetos de curso desse departamento parecem se repetir em outras experiências. Com outros atores, o roteiro coincide em muitos pontos. Assim, por mais que o foco seja específico (e, claro, com suas singularidades) é possível, a partir dele, perceber aspectos de alcance maior.

Para delimitar nosso objeto, vamos nos ater a dois direcionamentos. Em primeiro lugar, vamos nos restringir à análise das propostas de cursos de graduação. $O$ departamento aparece com essa intenção, sendo a primeira proposta elaborada em 1971. Em 1980, há uma reestruturação mais profunda. Na década de 1990, há a proposição de um curso de especialização tendo em vista a formulação de uma futura graduação. E, por fim, em 2011 há

\footnotetext{
${ }^{2}$ Nas palavras de Wach, "As mesmas condições que se mostram muito frutifferas para o trabalho prático tem disso menos favoráveis à reflexão teórica. Ainda hoje, os fundamentos sistemáticos da ciência da religião são bastante insatisfatórios" (WACH, 1988, p.07).

${ }^{3}$ Gostaria de agradecer aos professores Faustino Teixeira e Paulo Agostinho pela leitura prévia do texto e sugestões. Ambos, enquanto alunos da graduação em C. da Religião da década de 1970 na UFJF, tomaram parte nesses acontecimentos.
}

\section{3}


um novo projeto pedagógico, que atualmente se encontra em andamento. Conscientemente, estamos deixando de fora uma parte importante da história que é a construção e consolidação da pós-graduação. Dada a complexidade do tema, penso que deveria ser abordado à parte e em outro momento.

Em segundo lugar, no intuito de se evitar uma abordagem histórica puramente factual e investir numa aproximação reflexiva, uma pergunta nos guiará: qual a concepção de ciência da religião que está subjacente a cada projeto pedagógico proposto? Em cada um, nota-se por meio das disciplinas, da justificativa do curso, de seus objetivos, perfil do egresso etc. como a compreensão de cada período gera práticas pedagógicas e curriculares. No caso de Juiz de Fora não somente houve alternância quanto ao nome (primeiramente, Ciências das Religiões depois Ciência das Religiões e, por fim, Ciência da Religião), mas também quanto às concepções que os projetos pedagógicos espelham. $\dot{E}$ provável que, como acontece atualmente, não tenha havido unanimidade sobre a compreensão de $C$. da Religião por parte de todos os docentes de cada período. No entanto, os projetos pedagógicos expressama opinião compartilhada pela maioria, até mesmo porque eles foramaprovados pelos colegiados para poderem ser implementados.

\section{1) Um curso em busca de legitimidade institucional (1970-1979) 1.1 projeto do curso de graduação}

Nesse primeiro momento destacam-se dois elementos que se complementam. $\bigcirc$ curso nasce sob aprofunda influência da teologia em sua concepção epistemológica. Aliás, a proposta inicial era de que fosse fundado na UFJF um departamento de teologia. $O$ nome Ciências da Religião é uma contraproposta do Conselho Federal de Educação. Além disso, diante de ataques vindos, de um lado de setores positivistas da universidade e, de outro, de eclesiásticos, o curso vai se afirmando como distinto da teologia. Nesse momento, os entendimentos mais propositivos do curso se constroem nesse diálogo.

O Departamento de Ciências das Religiões (nome original) da Universidade Federal de Juiz de Fora (UFJF) tem seu início a partir de uma reestruturação pela qual a universidade passava em 1968. Apesar da UFJF ter sido criada oito anos antes, viu-se a necessidade de se empreender essa reestruturação em virtude do seu crescimento.

O plano inicial era que a universidade contasse com um Departamento de Teologia. Essa proposta é enviada, junto com outros itens relativos à reestruturação da universidade, ao órgão do Ministério da Educação, responsável por avaliar sua pertinência. O Conselho Federal de Educação (CFE) faz uma série de ponderações.O documento, assinado por Newton Sucupira em 15 de Março de 1968, diz o seguinte:

No que se refere à Teologia, entendemos que não pode constituir unidade ou subunidade autônoma do sistema das ciências básicas, pelo menos, tais como definidas na lei. Certamente a Teologia que se tem em vista não é a Teologia da qual falava Aristóteles na Metafísica, nem a Teologia Natural que se costuma chamar Teodicéia desde os tempos de Leibniz e que é uma parte da Metafísica na classificação Wolffiana. É a Teologia Dogmática, ciência do divino como tal que pressupõe formalmente a Teologia, embora utilizando-se de instrumento conceitual próprio. Assim considerada, como bem acentua J. B. Metz, discípulo de um dos mais eminentes teólogos modernos, Karl Rohner [sic], a Teologia distinguindo-se da pura Filosofia da Religião, tem na fé a base e a finalidade de seu Leges [Cf. Lexikon für Theologie und Kircheh [sic], Bd.XVerlag Herder Feiburg - 1965). Tradicionalmente, os estudos teológicos, nas universidades que possuem Faculdade de Teologia, são considerados como saber de

\section{4}


cúpula, destinos à formação profissional do clero, pressupondo o que hoje chamamos de formação básica.

Por estes motivos, sugerimos que, em vez de Instituto de Teologia, esja [sic] criado no Insttituto [sic] de Ciências Humanas um Departamento de Ciências da Religião, neste Departamento o fenômeno religioso pode ser estudado em seus vários aspectos, podendo ser ministrados cursos sôbre e de Teologia (Parecer No. 190/68, aprovado em 15 de Março de 1968, Processo 733/67 - CFE).(cf. Anexo 1)

Este documento, certidão de nascimento das Ciências da Religião no Brasil, não obstante diversos erros de datilografia, é claro em sua intenção: considera inviável a proposta de uma teologia dogmática e sugere o nome Ciências da Religião. Alguns aspectos são importantes para se compreender o que está em jogo. Em primeiro lugar, a reforma que se propunha na época era relativa às, assim denominadas, ciências básicas. A teologia, obviamente, não estava inclusa nesse grupo, o que torna a proposta, de início, inviável. Mas, o documento não se detém aqui. Ele traz uma argumentação ao apontar para três tipos possíveis de teologia. As duas primeiras articuladas com o campo disciplinar da filosofia denominada de metafísica. Há a teologia como filosofia primeira - que busca pelos princípios e fundamentos - tal como encontramos em Aristóteles.Há ainda a teodiceia,que não se constitui propriamente um campo, mas é uma subdivisão da metafisica. E, por fim, há a teologia dogmática. Esta teria finalidade claramente religiosa e prática, no sentido de formação do clero, estando sob os auspícios da igreja. Portanto, o assunto cabe à cúpula (ou seja, é de interesse da igreja), do que se pode deduzir que não cabe às instâncias governamentais intervenção nessa questão.

Esse documento tem grande valor histórico. Se considerarmos que esse departamento é o primeiro com esse nome no Brasil, podemos concluir que o nome de Ciências da Religião não surge a partir da base, mas é sugerido por um órgão oficial do próprio MEC. Portanto, quem recomenda a criação de um curso com esse nome é próprio Ministério da Educação. $O$ nome proposto, já nessa ocasião, é Ciências da Religião(ciências no plural):o mesmo que se utiliza atualmente na área 44 da CAPES. E mais do que isso. Admite-se que se possa ensinar teologia, desde que ela apareça ao lado de outros elementos constitutivos do fenômeno religioso.Em suma, não pode haver exclusividade da teologia, mas ela não é suprimida.

A sugestão é acatada pela UFJF, mas com alterações. $O$ projeto foi implementado pelo Departamento de Filosofia, o que levou à criação do colegiado do curso de Ciências das Religiões em 27/06/1969. No entanto, somente em 1971, é criado o Departamento que, até onde nos é permitido saber, é o primeiro dessa natureza na América do Sul. A nomenclatura do curso não segue a indicação do Conselho Federal de Educação, mas adota "Ciências das Religiões".No entanto, isso não acarretou maior reflexão acerca da necessidade de se repensar o próprio projeto do curso de graduação. Em termos mais claros, sob o nome de Ciências das Religiões oferecia-se um formação com contornos claramente teológicos. Ao mesmo tempo, entretanto, a preocupação de inserção do estudo da religião na universidade pública leva a afirmar que esse estudo era feito de modo sistemático e a confessional. Foram necessários alguns anos e muitos debates para que se alcançasse maior clareza sobre a repercussão da mudança da nomenclatura..

$\mathrm{Na}$ ata de fundação do Departamento de Ciências das Religiões, consta que ele teria por objetivo possibilitar "o estudo sistemático e aconfessional do fenômeno da religiosidade". No perfil do egresso, aponta-se que o diplomado "teria as funções de professor de religião em estabelecimentos de ensino, orientador religioso-moral e técnico em assuntos religiosos para assessorar os poderes públicos e as organizações sócio-econômicas" (Ata do núcleo de Ciências das Religiões, 10/07/1969). O projeto justifica o curso afirmando a necessidade para a universidade de reflexões filosóficas e teológicas, uma vez assumido o caráter universalista

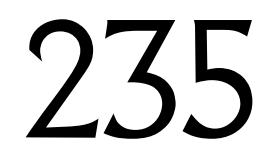


desses dois sabres. Dessa maneira, um dos propósitos do futuro Departamento era promover estudos teológicos em nível superior. Afirmações desse teor mostram como a modificação no nome do departamento não implicou, ao menos inicialmente, em reestruturações mais profundas. Ao lado disso, destacava-se também que uma de suas metas era "a promoção do diálogo entre as grandes religiões, sobretudo da religião que é servida pela UFJF" (Ata do núcleo de Ciências das Religiões de 10/07/1969), ou seja, o cristianismo. Em termos concretos, isso se manifestou na seguinte proposta curricular (Ata de 24/03/1970; Processo 3048/71):

\begin{tabular}{|l|l|}
\hline Ciclo Básico & Específicas \\
\hline Sociologia I & Ética I e II \\
Civilização Contemporânea & Antropologia Religiosa \\
Português I & Sociologia VI (Antropologia da Religião) \\
Introdução à Psicologia & Introdução ao Mundo Bíblico I-II \\
Introdução à Filosofia & Hermenêutica Bíblica I-II-III \\
& Cristologia Bíblica \\
& Escatologia Bíblica \\
& Cristologia Sistemática \\
& Eclesiologia Sistemática \\
& História do Cristianismo I-II-III-IV \\
& Fenomenologia do Cristianismo I-II-III-IV \\
& Estudo Comparado das Religiões I-II \\
& Psicologia da Religião \\
& Filosofia da Religião I-II \\
\hline
\end{tabular}

O curso era dividido em dois momentos, perfazendo um total de oito semestres letivos. Em primeiro lugar, havia a preocupação de oferecer aos estudantes uma formação mais geral, dialogando com as ciências humanas: filosofia, sociologia, história, psicologia, etc. $\mathrm{Na}$ segunda etapa, que constitui o curso propriamente dito, assinala-se a presença de dois tipos de disciplinas. Há aquelas que intentam contemplar como determinadas áreas do saber lidam com o fenômeno religioso: filosofia, sociologia, antropologia, psicologia e/ou tratam de determinados temas atinentes à religião (concepção de ser humano, ética). Ao lado desses conteúdos curriculares, constata-se a forte presença de disciplinas atinentes à tradição cristã, desde assuntos práticos, passando por bíblicos e sistemáticos até os históricos. A julgar apenas por essas disciplinas, percebe-se a ausência de referência a outras tradições religiosas, com exceção de Estudo comparado das religiões I e II.

Como, então, compreender que se defenda um estudo aconfessional e sistemático com essa moldura teológica que o curso assume? Estamos diante de flagrante contradição entre o que se sonhava e o que se realizou? Pelo que se depreende, estudar o fenômeno da religiosidade de um ponto de vista aconfessional significava, nesse momento, lidar com temas da tradição cristã sem assumir uma postura meramente apologética. Desse modo, no aconfessional não se inclui o estudo de tradições religiosas e temas para além daqueles limitados e caros ao cristianismo (ainda que o curso se denominasse "Ciências das religiões"), mas significa tratar dessa tradição, que constitui o quadro de referências do Ocidente, de maneira, digamos, "mais arejada".

Não é gratuito, portanto, que o clero local se sentisse ameaçado pelo curso. As matérias estudadas são típicas de um curso de teologia. $O$ diferencial, ao que parece, estava no tratamento que se dispensava a elas. Além de sistemática, buscava não ser confessional. Isso é sinal de que essa proposta, não obstante sua forte concentração no cristianismo, inquiria por 
uma visada sobre os temas para além dos cânones eclesiásticos e interpretações oficiais, despertando a atenção dos líderes religiosos locais.

Se ao olhar contemporâneo essa proposta soa por demais teológica, cabe inseri-la dentro do contexto do qual emerge e o papel que aí desempenhou.Nas circunstâncias da época, representou um avanço, afinal questionava-se tanto o positivismo arraigado em nossa cultura acadêmica bem como a abordagem dogmatizante das instituições eclesiásticas. Aliás, com algumas exceções bem pontuais, os seminários eram até então o lugar de estudo da religião em nível superior no Brasil. Além disso, esse currículo explicita a hipótese de que a Ciência da Religião no Brasil (tanto no âmbito da graduação como da pós) surge numa inequívoca proximidade com a teologia. Aliás, cumpre notar que grande parte do corpo docente era constituído de professores com alguma trajetória e/ou engajamento eclesiástico, em sua grande maioria padres (sobre isso, TEIXEIRA, 2013). Poder-se-ia mesmo dizer que a Ciência da Religião aparece como tentativa de se fazer teologia sem os cerceamentos que as instituições religiosas impõem àqueles que a elas estão vinculados (sobre isso, cf. GROSS, 2012, p.15).

Nesse momento, também se vislumbrava algumas sendas a serem abertas. A ata da reunião de 25/04/1975 predizia que "Estudo Comparado das Religiões" deveria assumir gradativamente uma posição mais privilegiada, inclusive se desdobrando em outras novas disciplinas. Mesmo que timidamente, parece haver gradativo reconhecimento da necessidade de abordagem de outras tradições religiosas. Isso se percebe nas referências que se faz ao estudo da religiosidade popular e dos cultos afro-brasileiros (Ata do Depto. de C. das Religiões, 25/04/1975), ao kardecismo (Ata do Depto. de C. das Religiões 08/03/1977) e, posteriormente, ao Islã. No entanto, havia um problema sério nessa conjuntura: encontrar especialistas que abordassem essas temáticas de maneira não apologética.

\section{2 projeto de uma licenciatura em Ciências das religiões}

Por meio do Aviso 142 de 07/02/1974, a UFJF consulta o Conselho Federal de Educação sobre a possibilidade do estabelecimento de um currículo mínimo para um curso superior: Licenciatura em Ciências das Religiões 4 . A fim de mostrar a relevância da matéria, não somente se envia uma consulta, mas também se argumenta em favor da necessidade do curso. Do ponto de vista teórico, sublinha-se a relevância social da religião, o que justifica a formação de um profissional que a estude mais sistematicamente. Em termos práticos, colocam-se mais duas alegações. Com atenção à formação dos conselhos municipais de educação e cultura, destaca-se o papel de especialistas em religião para assessoria de órgãos públicos e outros organismos. O outro argumento, por fim,segue na direção de se ter profissionais habilitados para atuação na escola na disciplina de Ensino Religioso. Nas palavras do documento:

(...) é de se notar que o ensino da religião (ou da cultura religiosa) é obrigatório em vários Estados da União. Os ministros de religião, geralmente convidados para esta tarefa, nem sempre apresentam a qualificação requerida. Falta-lhes muitas vezes, o preparo didático e pedagógico, e facilmente pode Ihes faltar aquela abertura de espírito que permita o desenvolvimento imparcial, inter-confessional e respeitoso dos temas. Um licenciado em Ciência das Religiões, formado através de um currículo fixado pelo MEC, teria, em tese, melhores condições para o desempenho satisfatório do tema (Aviso 142 de $07 / 02 / 1974)$.

\footnotetext{
4 Nesse momento, de maneira independente, há iniciativas em Santa Catarina para o início de uma licenciatura em Educação Religiosa. Essa proposta, reiterada sucessivas vezes, foi recusada pelo Conselho Federal de Educação (CFE) com base em razões legais.Sobre isso, cf. OLIVEIRA, 2003.
} 
Vale observar como, de maneira relativamente rápida, aquilo que se denominava como a-confessional toma forma. A justificativa central da licenciatura é que esse profissional estaria mais aberto a outras tradições religiosas, num espírito mais ecumênico. Inclusive, o mesmo documento propõe um esboço de como poderia se configurar esse currículo mínimo:

\section{Currículo Mínimo do curso de Ciência das Religiões}

3.1 - A licenciatura em Ciência das Religiões será de 2.200 horas/aula, tendo a duração mínima de 3 e máxima de 6 anos.

3.2 - O currículo mínimo compreenderá as seguintes disciplinas

3.2.1 - Tronco comum:

1.Estudo Comparado das Religiões

2. Filosofia da Religião

3. Sociologia da Religião

4. Psicologia da Religião

5. Introdução ao Mundo Bíblico

6. História do cristianismo

3.2.2 Disciplinas de Especificação, referentes ao aprofundamento das grandes religiões (ou grupo de religiões).

7. Hermenêutica do(s) livro(s) sagrado(s) da religião escolhida.

8. Fenomenologia da religião escolhida (ou grupo de religiões).

3.3 - As disciplinas 7 e 8, compreenderão um mínimo de $20 \%$ e um máximo de $30 \%$ de carga horária total.

3.4 - Para o funcionamento do curso, a entidade mantenedora deverá oferecer, além das disciplinas do tronco comum, as disciplinas de especialização de pelo menos uma religião.

3.5 - As disciplinas 1 a 4 compõem o programa, praticamente já consagrado nas Universidades da Europa, da chamada 'Ciência das religiões' (Religionswissenschaft). As disciplinas 5 e 6 foram colocadas no tronco comum, porque o mundo bíblico e o cristianismo representam inegavelmente os fundamentos religiosos da civilização ocidental. Mesmo se alguém quiser especializar-se nas religiões afro-brasileiras, no islamismo, no budismo, etc., ser-lhe-á necessário conhecer esses fundamentos. As disciplinas 7 e 8 foram colocadas para dar maior flexibilidade e para evitar ao mesmo tempo unilateralismo confessional e superficialidade(Aviso 142 de 07/02/1974).

É preciso ressaltar o caráter inovador da proposta, pensando-se que foi formulada num momento em que não havia outros departamentos da área no Brasil e que, somente em 2018 tem início a discussão em torno de parâmetros curriculares para esses cursos. A resposta negativa do CFE demonstra não ter entendido a proposição. O professor B.P. Bittencourt, parecerista do tema,solicitou auxílio à Faculdade de Teologia da Igreja Metodista de S. Bernardo e ao Seminário São Francisco - Nova Veneza de Campinas - SP. O parecer é negativo quanto à possibilidade de haver licenciatura, incentivando o bacharelado. Inclusive, menciona que esses pareceres são meramente consultivos, não tendo poder normativo(Anexo 2).

O argumento para a negativa da proposta, especialmente redigido pelo Seminário São Francisco,tem um pressuposto claro: estudar religião equivale à pregação religiosa. $O$ parecer parte da ideia equivocada de que não é possível o estudo sobre o fenômeno religioso,

\section{8}


constituindo-o como objeto. Mas, toda aproximação da religião é e implica em propagação de confissões religiosas.

Em termos textuais, isso aparece do seguinte modo no documento: "Tem sido praxe deste egrégio Conselho não interferir na área da religião, nem mesmo para aprovar os professores que são indicados para os cursos de Religião ou Cultura Religiosa mantidos por escolas confessionais ou não" (Parecer no.2244/74, Processo 6.930/74 CFE, p.331). Ou seja, na concepção aqui expressa, o Conselho entende que arbitrar quanto às disciplinas ou mesmo conteúdos de disciplinas de curso superior sobre religião seria interferência no âmbito religioso, o que estaria fora de sua competência. Esse tipo de argumento somente faz sentido quando não se distingue entre estudar sobre religião e pregar determinada religião5.

A outra linha argumentativa, que parte do mesmo pressuposto, pergunta-se quanto à formação do egresso. Quanto a esse aspecto, outro ponto é acrescido. Uma vez que não há distinção entre estudar sobre religião e praticar religião, entende-se que somente um egresso a-religioso poderia ser suficientemente cientista das religiões, por ser imparcial, isto é, não comprometido como nenhuma tradição religiosa. Nas palavras do próprio documento:

Parece existir uma incoerência na exposição dos motivos que levam à criação do sobredito curso. É possível criar uma "ciência das religiões" imparcial, se o próprio currículo prevê uma especialização em determinada religião? É possível formar um cientista das religiões completamente a-religioso?

(...)

Impossivel seria uma licenciatura em Ciências das Religiões que preparasse o professor de Religião cientificamente imparcial. E se ele fosse preparado através de um currículo também confessional, não só estaria prejudicado para o magistério em qualquer circunstância, como também daria à Universidade Federal de Juiz de Fora a tonalidade confessional eu ela não deseja nem pode ter. (Parecer no.2244/74, Processo 6.930/74 CFE, p.331)

É curioso o argumento do parecer. Quando observamos a história, a formação de professores de Ensino Religioso para o magistério na educação básica, no período em que a proposta é feita e durante muito tempo depois, foi realizada por meio de cursos ofertados por instituições eclesiásticas, com tom claramente confessional. Ou seja, a proposta, mesmo se tivesse todos os limites que o parecer indica, já teria sido um avanço. Mas, como se pode notar por esse parecer, a proposta sequer foi entendida.

Mesmo diante da negativa da licenciatura, o compromisso em se oferecer formação para professores de Ensino Religioso não recuou no âmbito do departamento de CR da UFJF.

\footnotetext{
5 Em parte, essa negativa pode ser entendida por uma questão legal. A LDB de 1961, em seu artigo 97 dizia:Art. 97. "O ensino religioso constitui disciplina dos horários das escolas oficiais, é de matrícula facultativa, e será ministrado sem ônus para os poderes públicos, de acôrdo com a confissão religiosa do aluno, manifestada por êle, se fôr capaz, ou pelo seu representante legal ou responsável.
}

$\S 1^{\circ}$ A formação de classe para o ensino religioso independe de número mínimo de alunos.

\section{$\S 2^{\circ} \mathrm{O}$ registro dos professôres de ensino religioso será realizado perante a autoridade religiosa respectiva".}

Cabe ainda destacar que a LBD, no seu artigo $97 \S 2^{\circ}$ atribuía às autoridades religiosas o registro dos professores de Ensino Religioso. Assim, na prática, as autoridades eclesiásticas indicavam o professor de Ensino Religioso. E, aceitar a pertinência de um curso dessa natureza significava reduzir a ascendência eclesiástica sobre a disciplina.

\section{9}


Como exemplo, dentre vários, vinte anos depois pode-se ler na ata de reunião do departamento: "O depto. foi solicitado pelo DRE para um curso de reciclagem de professores de $1^{\circ}$. e $2^{\circ}$. Graus. Tal proposta foi aceita por todos os membros do departamento de Ciência da Religião e ainda contribuir de forma efetiva na formação de outros profissionais" (Ata do Departamento de Ciência da Religião, 08/05/1995).

Ainda, para concluir esse tópico sobre o pedido do curso de licenciatura e o respectivo parecer negativo, há um registro de uma intervenção do prof. Jaime Snoek, como representante do Instituto de Ciências Humanas e Letras (ICHL) no Conselho Superior Universitário (CONSU) em que revela acontecimentos de bastidores. Essa intervenção foi feita quatro anos depois da solicitação:

Quando a UFJF em 1974 solicitou a aprovação de uma licenciatura em CR, o relator, pastor metodista, tinha elaborado um parecer favorável, mas ele foi pressionado a mudálo. O próprio relator revelou isto ao Rev. Domício Pereira, professor do Departamento, e acrescentou que continua favorável". Jaime Snoek ainda aponta alguns equívocos no parecer. Ele diz que "não cabe competência em assunto de religião". "Aqui se confunde fé e religião. É claro que não Ihe cabe competência em assuntos de fé, enquanto expressam em determinado credo, mas dizer que não Ihe cabe competência em assunto de religião equivale a riscar da Antropologia cultural o capítulo que lhe diz respeito, equivale a desautorizar a UNICMP [sic] que acaba de lançar o primeiro número de uma revista especializada Religião e sociedade (Ata Reunião do Conselho Universitário da UFJF, 02/09/1977).

Destaca-se que houve pressão para o que relator se manifestasse contrariamente ao curso de licenciatura. $\mathrm{Ou}$, pelo menos, ele assim disse quando interpelado por um professor do curso. Pela fala de Snoek, percebe-se que já à época ficou evidente essa confusão entre estudo sobre religião e prática religiosa (fé). A fé se relaciona com a consciência individual, ao passo que a religião assume dimensão pública, compondo parte importante da cultura. Naquela, não cabe intervenção do estado. No entanto, no que diz respeito à religião como parte formadora da cultura, são possíveis e necessários posicionamentos acadêmicos e institucionais (inclusive do CFE). E, por fim, aparece aqui um recurso argumentativo que se repetirá outras vezes. Afirma-se a legitimidade do curso indicando que há outras universidades com mais prestígio que estão atentas ao estudo do fenômeno religioso. Neste caso, o exemplo utilizado é a Unicamp.

\subsection{Debates, controvérsias e a suspensão do curso: o tumultuado ano de 1977}

Depois de anos de elaboração e reformulações, em 1975, o curso de Ciência das Religiões foi implementado pela resolução 32/75 do Conselho Superior (Consu) da UFJF e 35/75 do Conselho de Ensino, pesquisa e extensão (CEPE) da UFJF. No entanto, isso não significou o fim das resistências à proposta.

Mediante a recusa de abertura da licenciatura, o curso de bacharelado tem início. Foram realizados dois vestibulares. Em 1976, foram abertas 10 vagas para 13 candidatos. Já em 1977, apareceram 9 candidatos, sendo que outros três pretendiam se inscrever para o curso, mas se candidataram por engano para filosofiab.

${ }^{6}$ Em conversa com alunos da época, Faustino Teixeira e Paulo Agostinho relataram que se lembravam de ter ocorrido apenas um processo seletivo. No entanto, encontrei uma papel com anotações do prof. Jaime Snoek em que indica a realização de dois vestibulares (vide anexo 3). 
É neste momento que o curso sofre sua maior oposição, partindo de setores internos da própria universidade (oposição de professores e do reitor), como de setores eclesiásticos. $\bigcirc$ debate foi intenso, extrapolando para as páginas dos jornais locais. De um lado, havia manifestações pelo fechamento do curso. Em contrapartida, levantaram-se aqueles que defendiam sua continuidade. Antes de detalhar os argumentos de cada lado, vejamos como se deu a suspensão do caráter oficial do curso.

Desde o início de 1977, os documentos relatam rumores de uma movimentação para o fechamento do curso no ano seguinte. Diante disso, os professores começaram a se mobilizar. Como muitas vezes ocorre, esse complexo jogo não é disputado apenas na arena acadêmica, mas tem muito de político. Assim, por exemplo, há o relato de uma reunião que o Jaime Snoek manteve com D. Geraldo Maria de Morais Penido (bispo e arcebispo de Juiz de Fora entre 1958-1977) em 28/04/1977. Num dos tópicos sobre a conversa, relata:

Num encontro social Sebastião [reitor] disse a D. Geraldo [arcebispo]: "Este curso de religião na Universidade vai acabar no ano que vem". Logo entrou outro na conversa e não foi possível indagar melhor. Ficou de sondar isto na próxima oportunidade e de me informar. D. Geraldo pensa que é o Ministério que está atrás. Eu me pergunto se não será a Segurança, considerando a famosa frase do Pedro Paulo ao Henrique Olavo: “Esta teologia da libertação ainda vai botar muita gente na cadeia". Seja como fôr, Sebastião não fala assim por si próprio. Tem alguém atrás. (anexo5)

Há ainda o relato de outra reunião em 20/06/1977, com o reitor (anexo 6). O objetivo era inquirir quanto ao fechamento do curso. Nessa reunião, segundo nos narraSnoek, o reitor diz que não se coloca contra o curso, mas que pretende investigar sua legalidade. Ao final da reunião, Snoek pergunta se alguém havia dado ao reitor instruções quanto ao encerramento do curso. Ele, de sobressalto, negou. No entanto, essa negativa não foi suficiente para eliminar as suspeitas de Snoek quanto ao fato de que havia outras forças interessadas no fechamento do curso. É preciso considerar que estamos em plena ditadura militar, de modo que as posturas políticas contestatórias de muitos professores do curso não eram bem vistas por setores alinhados ao regime ditatorial.

Na reunião do Conselho Universitário (CONSU) de 08 de Agosto de 1977, o processo relativo ao curso de Ciência da Religião é retirado de pauta. Argumenta-se necessidade de esclarecimentos quanto à sua legalidade, uma vez que não havia currículo mínimo para essa graduação. Por meio do ofício 3385/77, o reitor consulta o CFE se a universidade pode continuar ministrando o curso e se poderá pleitear o seu devido reconhecimento. A resposta é prontamente enviada pelo então presidente do CEF, Padre José Vieira Vasconcellos, no dia 24/08/1977, com os seguintes dizeres:

1. $O$ curso de Ciência das religiões só pode funcionar, nessa como em qualquer instituição de Ensino Superior, nos moldes em que foi aprovado pelo parecer no.190/68 do Conselho.

\section{Para o caso não importa a modalidade: licenciatura ou bacharelado.}

3. O CFE não baixou, nem baixará, currículo mínimo nesta área por entender, por jurisprudência unânime, que não lhe cabe competência em assunto de religião. Nem vale o argumento que a Lei Diretrizes e bases, prescrevendo como obrigatório o ensino religioso nas escolas oficiais, indiretamente confere ao CFE atribuição para deliberar sobre a formação de professores para esse ensino, uma vez que a mesma Lei estabelece que deliberar sobre esta formação compete às Autoridades Religiosas 
4. Tais cursos não podem usar nomenclatura (Faculdade, Universidade, Vestibulares, ou outras que tais) privativa de cursos regularmente autorizados pelo CFE.

5. Por igual motivo, nem pode a Universidade pleitear ao CFE o reconhecimento de tais cursos, nem abrir, para os nomes, concursos vestibulares (Ofício no. 5245/77 presidente do CFE)

Essa resposta é ambígua. De um lado, em virtude do parecer de 1968, reconhece que o curso poderá continuar funcionando desde que siga o que prescreve esse primeiro parecer. Entretanto, não reconhece a legitimidade do curso, inclusive vetando a realização de novo vestibular.

Na reunião do CONSU de 02/09/1977, é comunicada a decisão da suspensão do vestibular para o curso de Ciências das Religiões do ano seguinte. Isso é feito com base nesse parecer emitido pelo presidente do CFE. O prof. Jaime Snoek acata a não realização do vestibular, mas busca uma saída para evitar o fechamento total do curso:

Tomo a liberdade de lembrar que este of. no $.5245 / 77$ do Sr. Presidente do CEF não pode ser considerado como a pá de cal sobre o curso. O CFE é composto por 25 membros. O Ofício é do Presidente. Nada indica que ele tenha ouvido o plenário ou pelo menos a câmara de Ensino Superior. A data é de 24 de Agosto. O conselho se reuniu no dia 29. Pode-se duvidar se o presidente interpreta o pensamento comum dos Conselheiros. (Ata Reunião do Conselho Universitário da UFJF, 02/09/1977).

Nessa mesma fala no CONSU, Snoek, na tentativa de diminuir o impacto deste parecer do CFE, utiliza um argumento que não correspondia exatamente à realidade: o item 3 não poderia ser mais usado como argumento, uma vez que o departamento já havia abandonado a ideia de uma licenciatura e, portanto, não cabia mais a proibição do curso com base no argumento da indicação dos professor de Ensino Religioso por parte das instituições eclesiásticas. A proposição do curso, reforça ele, pautava-se no incentivo do Prof. Newton Sucupira (quando presidente do CFE) de que deveria haver novos bacharelados que não visassem meramente formação profissional. Esse era o caso do curso em questão.

Outro ponto que ganha expressão neste debate é a relação entre ciências das religiões e teologia.Como observado, nos primórdios do departamento, havia muitas sobreposições entre os dois campos. No entanto, a fim de defender a legitimidade do curso, J. Snoek aposta na distinção:

Pois, se a CR é entendida como análise de um campo específico de um comportamento humano, - e só dessa maneira que hoje se entende CR como distinta da Teologia, então a UFJF pode pleitear tranquilamente o reconhecimento de um bacharelado nesse sentido (Ata Reunião do Conselho Universitário da UFJF, 02/09/1977)7

Em resposta, o departamento de Ciência das Religiões, com anuência do reitor, envia uma carta memorial de esclarecimento aos conselheiros do CFE. É interessante como esse memorando externa certos esclarecimentos sobre a proposta do curso. Se anteriormente era

\footnotetext{
7 Essa mesma percepção já era anunciada na carta memorial enviada ao CFE em 22 de Agosto de 1977 e assinada pelo Depto. Aqui, aponta-se para essa distinção. A teologia é um discurso teórico da fé. Nesse quesito, não se confunde com a C. das Religiões. Apesar de distinta, ela não exclui a teologia, afinal o estudo das diversas teologias que moldam as mais variadas tradições religiosas é também alvo preocupação da $C$. das religiões. Assim, propõe a carta, enquanto os aspectos mais amplos dos fenômenos religiosos constituem uma parte geral da C. das Religiões, a teologia seria uma parte especial, de modo que o estudo de uma ou mais teologias é parte constituinte da formação do cientista da religião. (Carta memorial ao CFE, p.08).
} 
justificado pela necessidade de estudos mais amplos no ambiente universitário e que deveriam ser providos pela teologia e pela filosofia, agora não somente o objeto parece se ampliar, como também os objetivos. Sobre isso, em seu ponto 2.3, o memorial diz: "Se, simplificando, chamamos de religiosidade a atitude dinâmica de abertura do homem ao sentido radical (transcendente) de sua existência (P. Tillich), compete à Ciência das Religiões estudar, do ponto de vista fenomenológico, tal atitude e suas manifestações pessoais e comunitárias nas diversas culturas" (Carta memorial enviada ao CFE, p.06) 8 .

Essa passagem mostra que, de um lado, há uma preocupação de se tratar da religião no singular, ou seja, de uma noção geral de religião. Esta, por sua vez, não remete imediatamente a uma revelação ou cosia do gênero, mas tem a ver com uma disposição do ser humano que o conduz para questões últimas, como a referência ao pensamento de Paul Tillich indica. Por outro lado, há a preocupação de também tratar das manifestações desta estrutura antropológica nas diversas culturas, ou seja, no seu aspecto histórico. Portanto, se de um lado há o cuidado de entender os elementos estruturantes da religião, por outro há a atenção às manifestações empíricas em suas singularidades. Ainda, numa perspectiva mais contextual, o grupo atentava que era chegada a hora de que os próprios brasileiros fizessem uma fenomenologia de sua própria religiosidade, uma vez que empreendimentos dessa natureza já haviam sido realizados por pesquisadores estrangeiros. $E$, ainda, na tentativa de indicar a seriedade da proposta, a carta remete a duas publicações internacionais de grande repercussão e que se dedicaram ao tema, inclusive mapeando 2164 obras e artigos nesta área científica do saber $^{9}$.

No entanto, em sua resposta, o Conselho mantém a deliberação negativa quanto ao estabelecimento de um currículo mínimo. Isso, na prática, implicava no não reconhecimento do curso pelo Ministério da Educação e, consequentemente, sua inviabilidadelo.

A solução que se acha para o problema acabou por se valer da ambiguidade do parecer do presidente do CFE, que, na prática, não proibia o curso, mas vetava novo vestibular. Assim, o curso foi suspenso em seu caráter oficial. Isso significa que ele não deixou de existir, mas apenas não funcionaria mais com a chancela do Ministério da Educação, sendo espécie de curso livre. Como dizia um panfleto datilografado distribuído entre os alunos ingressantes em 1978: "O curso vale o que vale"(Anexos 7). Por outro lado, os alunos que haviam ingressado nos anos anteriores poderiam optar até o fim de 1977 por qualquer outro curso oferecido pelo instituto de ciências humanas (Resolução 55/77 do Conselho de Ensino, Pesquisa e extensão - CEPE).

\footnotetext{
8 Voltarei a analisar esse trecho posteriormente, uma vez que esse mesmo texto é utilizado para relatar o histórico do curso quando se solicita sua reestruturação em 1980.

9 Há referência BulletinSignalétiquéVVol. XXXI, no.01, 1977, publicado trimestralmente pelo Centro Nacional de Pesquisa Científica, com um número dedicado a Sicencesreligieuses. Esse número é dividido em duas grandes partes. Num primeiro momento, discutem-se aspectos epistemológicos das Ciências da Religião, desde metodologia a mito, mística, etc. A segunda parte, bastante mais extensa, dedica-se a várias tradições religiosas, com ênfase no cristianismo. A outra referência, à qual não tive acesso, é um grupo de Gröningen (Holanda) que se dedica ao estudo de C. da Religião. É plausível supor que seja uma alusão ao curso de C. da Religião mantido pela Universidade de Gröningen (http://www.rug.nl/bachelors/religiousstudies/research?lang=de - Site visitado em 05/10/2017).

10 A resposta veio por meio do ofício 050932/77 do CFE em 23 de Setembro de 1977. Sem discutir maiores questões epistemológicas, o parecer apenas se presta a dizer: "Infelizmente tais manifestações não infirmam os argumentos com que, em manifestações anteriores, este conselho comunicou à universidade a impossibilidade legal de uma oficialização de tal curso, como tinha sido solicitada, quer em nível de licenciatura ou de bacharelado". Chama a atenção que o Conselho, inclusive contrariando pareceres anteriores, não recomenda o reconhecimento também do bacharelado.
} 
Um capítulo importante desses acontecimentos foi o debate que a suspensão do curso provocou na cidade, inclusive ocupando as páginas dos jornais da época(anexos 8, 9 e 10). Os setores artísticos e intelectuais de Juiz de Forase articularam a partir do Centro de Estudos Tomás de Aquino promovendo ações na defesa do curso(Anexo 11). No jornal, há textos advogam sua pertinência, como outros atacando com veemência o que se considerava um atentado à universidade pública. As matérias saíram no Diário Mercantil de Juiz de Fora entre os dias 13 de Julho de 1977 e 10 de Agosto de 1977. A informação dessas datas é importante. Afinal, a veiculação das matérias acontece antes mesmo da retirada do curso da pauta da reunião do CONSU, o que indica que os rumores da suspensão do curso já eram bem mais do que rumores. Até mesmo o próprio jornal informa que o reitor havia solicitado o processo para averiguação (Diário Mercantil, 10 e 11/7/1977, p.04) e que no dia 27/07/1977 havia se manifestado por meio de nota que nenhuma atitude seria tomada quanto ao fechamento ou não do curso (Diário Mercantil, 28/7/1977, p.05).Desse debate, vale observar os principais argumentos.

Os defensores do curso buscavam mostrar sua respeitabilidade por estar presente nas universidades europeias dede fins do século XIX. Portanto, não se tratava de uma invenção de professores da UFJF, mas a proposta estava amparada numa reconhecida tradição.Aliado a isso, ressalta-se sempre o pioneirismo do curso, sendo o primeiro e único do gênero na América do Sul. Portanto, a proposta se pautava numa venerável tradição aliada a uma inovação para o contexto brasileiro"1.

Além disso, ressalta-se também a importância crescente que a religião assume no cenário social. Isso conduz à urgência da interpretação desse fenômeno. Como ilustração, há um artigo publicado no Diário Mercantil que diz:

No Brasil, vivemos o que poderíamos chamar de tempo forte das manifestações religiosas: movimentos carismáticos, pentecostes, cursilhos, aumento da frequência em terreiros de macumba, etc. É uma realidade incontestável. Paralelo, pois, a um cientificismo, cresce o número das que aderem a uma nova religião. Desconhecer isso é afastar-se de uma realidade objetiva e concreta (...) Se a Universidade deve se integrar na comunidade, onde estão os intelectuais e elementos mais esclarecidos de nossa cidade, para defenderem a continuidade do Curso de C. das Religiões - essa iniciativa pioneira que tenta colocar nossa UFJF no nível das Universidades Europeias? (Diário Mercantil, 12/07/1977, p.06).

Nesses embates, destacava-se que o objeto de estudo das Ciências das Religiões não é a religião, mas a religiosidade. Portanto, também não deve ser confundida com teologia, mas abrange um escopo maior, tanto no que concerne às tradições religiosas como em relação ao seu objetivo final. Assim, a Ciência das Religiões se ocupa não somente com a dimensão institucional (a religião), ou com uma tradição, mas com essa abertura do ser humano ao transcendente que assume diversas configurações histórico-sociais.Para os defensores do curso, ao menos em teoria, tratava-se não de um estudo proselitista ou confessional, mas científico e objetivo, tendo muito a contribuir para o conhecimento humano. $O$ coordenador do curso à época, prof. Vitorino Nunes Duarte, declarou ao Diário Mercantil, "O curso não é nem pode ser de cunho proselitista ou confessional. Não exclui a análise exaustiva de uma religião. Afinal

\footnotetext{
" Em artigo publicado em 20/07/1977, Faustino Teixeira, à época aluno do curso, afirma: "Quero manifestar minha preocupação diante da possibilidade da eliminação do curso de Ciência das Religiões da Universidade Federal de Juiz de Fora. É lamentável que uma Universidade federal não tenha autonomia para respeitar e compreender a dimensão e importância de um curso que é altamente valorizado na Europa" (TEIXEIRA, F. "Ciência das Religiões". 20/07/1977, Diário Mercantil, p.10) Anexo 5
}

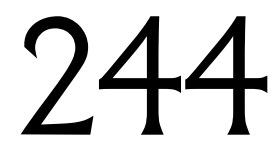


uma escolha deve ser feita. Sem sectarismos, com abertura total a todas as formas de manifestação religiosa, o curso não se define por essa ou por aquela religião" (Diário Mercantil, 27/07/1977, p.05)12.

Por fim, outra alegação recorrente, não obstante se tratar de um bacharelado, é a contribuição que o curso poderia dar para a formação de professores de Ensino Religioso. A argumentação distinguia entre catequese e Ensino Religioso. Numa declaração ao jornal, o então estudante Faustino Teixeira diz: "O curso de Ciência das Religiões vai procurar justamente enforcar a religiosidade de maneira científica e não confessional. $O$ ensino religioso confessional discrimina, divide, facilmente gera competição e rivalidade e consequentemente induz ao proselitismo (ainda que disfarçado - o que é mais perigoso)" (Estudante defende curso que UFJF pode extinguir. Diário Mercantil, 13/07/1977, p.04).

Nessa discussão pública, manifestaram-se vários professores e alunos, dentre eles Ignácio Delgado (à época, líder estudantil), Mozart Noronha e o Professor Hilton Japiassu (UFRJ). Três dias após a publicação do primeiro texto do professor da faculdade de Direito da UFJF Almir de Oliveira atacando fortemente a iniciativa do curso, há um extenso artigo de Japiassu, do qual destaco a seguinte passagem:

A Universidade de Juiz de Fora estava de parabéns. Porque havia ousado superar o velho ranço positivista, com seus preconceitos obscurantistas, e instaurado em seu seio o curso de Ciências das Religiões. Fato pioneiro no Brasil. E único. Digno da grande envergadura de inteligência de quem lutou por tal implantação. Apesar de ser um curso que, na mentalidade dos que não pensam, dos burocratas do saber, dos que são comandados por uma filosofia mercantilista e pragmatista, dos que reduzem o saber a uma ideologia pecuniária do "status" que possa conferir a formação universitária. (...) Seria lamentável que a inteligência dos homens de Juiz de Fora viesse, de vez, a esclerosar-se; que sua visão se tornasse míope; que sua mentalidade fosse tão provinciana e pequena para ter medo de um curso que só vem ampliar os horizontes mentais... (JAPIASSU, H. Ciência das Religiões, Diário Mercantil, 15/07/1977, p.02).(Anexo8)

Japiassu se posiciona contrariamente aos positivistas, que tendem a não considerar o fenômeno religioso como algo digno de ser estudado, muito menos com méritos para constituir em torno de si uma área específica de estudos. No contexto da ditadura militar, positivismo também é associado a uma visão meramente mercantilista de universidade, como se ela tivesse a reduzida função de formar mão-de-obra técnica, eximindo-se de reflexões teóricas e críticas.

Em número reduzido, apareceram também manifestações contrárias o curso. Elas são assinadas por Almir de Oliveira13, professor da Faculdade de Direito da UFJF. Em meio ao tom virulento de suas acusações podem se auferir os seguintes argumentos.

\footnotetext{
12 Apesar de haver bastante sintonia nos argumentos que as matérias trazem, há também algumas que divergem. Numa declaração Maria do Céu Correa Mendes, que chegou a liderar uma comissão contra o fechamento do curso, diz: "é estranho falar em fechar um instituto de alta cultura, porque aproxima da verdade consciente e sofrida que atrai o homem prô alto que o torna mais consciente nas suas relações com o transcendente" (Professora que defendeu Grupos Centrais quer garantir curso na UFJF. Diário do Comércio, 15/07/1977, p,04).

13 Formado em Direito em 1943. Desempenhou um papel importante na constituição da UFJF, sendo Diretor da Faculdade de Direito de 1964 a 1971, exercendo também a função de sub-reitor. Em 2010, foi condecorado com a medalha JK, a mais alta honraria da concedida pela UFJF. Faleceu em 2015 aos 99 anos.
}

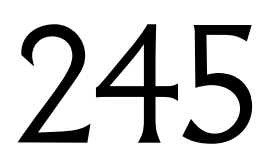


Se para os defensores, o pioneirismo era uma virtude, o mesmo fato não recebia a igual valoração pelos opositores. No primeiro texto publicado no Diário Mercantil, Almir de Oliveira, com o título o curso que não existe, logo de início afirma: "É uma excrescência. Não tem razão de ser. Nenhuma universidade no Brasil tem essa coisa" 10 curso que não existe. Diário Mercantil, 16/07/1977, p.02 - Anexo 9). Para ele, a novidade do curso não Ihe conferia mérito, mas seria invenção absurda. $O$ ponto de sua argumentação é que uma vez não havendo currículo mínimo, o curso não existe, ou seria um "curso fantasma". Portanto, em seu veredicto, fazer-se-ia muito bem em extingui-lo.

Outro argumento se refere à laicidade, ou no vocabulário da época, o Brasil como um estado "leigo". Dada essa condição, não caberia à universidade sustentar um curso dessa natureza. Quanto mais, assegura o professor, em se tratando de um curso que tem por vergonha se mostrar o que realmente é: teologia. Em sua leitura, ele seria um meio de abrigar alunos e professores oriundos do fechamento do Seminário da Floresta - seminário católico que funcionou na cidade até fins da década de 1960. Nessa direção, Almir de Oliveira indaga:

(...) o Estado brasileiro é leigo por força da constituição. Então, há de se perguntar: que Teologia se ensinará na Universidade? A cristã (católica, ortodoxa, ou protestante?), a budista, xintoísta, a mulçumana, a taoista, a brahmânica, a judaica, a confundiana? Todas elas, para ressalvar a neutralidade do estado em face das religiões? E onde encontrar os professores de todas elas? Arranjar um teólogo, que o seja de verdade, é tão difícil no meio católico, neste Brasil de católicos, quanto mais dez teólogos (OLIVEIRA, Almir. O curso que não existe. Diário Mercantil, 16/07/1977, p.2).

Por fim, uma vez que o curso é muito especializado, haveria pouca procura. Aliás, segundo propõe Almir de Oliveira, ele deveria ficar no seminário. É interessante que, para além das alegações mais situadas, esse raciocínio reproduz certa noção vigente no Brasil de que as instituições religiosas seriam o lugar apropriado para o estudo da religião, não cabendo essa função a instituições superiores não religiosas(OLIVEIRA, Almir. $\bigcirc$ "curso" e seus defensores. Diário Mercantil, 31/07/1977, p.2).

Os textos de Almir de Oliveira são bem ácidos e esboçam essa linha de argumentação. Infelizmente, eles se perdem em ataques pessoais, vociferando desqualificações, relegando o debate de ideias para segundo plano (Anexo 12). Por exemplo, há uma desqualificação quanto ao modo como a disciplina "Introdução ao Mundo Bíblico" era ministrada, acusando-a de ser um meio fácil para os alunos conseguirem créditos para se formar. Em defesa, WolfgangGruen argumenta que essa disciplina foi a primeira a ser ministrada no Brasil adotando a crítica da redação como metodologia de abordagem do texto bíblico ${ }^{14}$. Ou ainda, em outro texto:

Positivamente, isto não é difundir cultura, não é "ampliar horizontes mentais" nem é criar o "poder da cultura e do pensamento", como quer esse presunçoso Hilton Japiassu, que devia tomar umas aulas de português I com a Nadime Bara, para não encher o jornal de cacografias, como encheu, nem tropeçar na sintaxe da língua nacional, como tropeçou, no seu amontoado de desaforos, publicados no dia 20 de Julho. ${ }^{15}$

\footnotetext{
14 Esse fato é relatado pelo professor W. Gruen numa carta de 24/07/1977 endereçada ao Diretor do ICHL (Prof. Guilherme G.M. van Keulen). Além de lamentar o fato e o modo como a acusação foi feita pelo seu colega de universidade, ele se defende das acusações feitas pelo prof. Almir.

15 Mais um exemplo: “Ainda não houve quem tivesse coragem de pôr fim a essa farsa: um Curso que não dá 'status' profissional a ninguém, que não serve pra nada, senão para criar problemas para a Universidade" (OLIVEIRA, Almir. O curso que não existe. Diário Mercantil, 16/07/1977, p.02).
} 
O curso foi também alvo de crítica de atores que, aparentemente, se situam no outro extremo dos positivistas: os líderes eclesiásticos. É curioso que quando se trata de levantar suspeições quanto ao estudo da religião na universidade (e, neste caso, pública), por mais que empreguem argumentos distintos, positivistas e religiosos acabam dando as mãos. Havia uma oposição mais forte de setores eclesiástico da região, especialmente o então arcebispo de Juiz de Fora.Não houve contestação organizada de toda a igreja, mas de algumas lideranças, especialmente locais. Inclusive, em uma carta à CNBB, Snoek busca apoio para o curso (Anexo 4).

Em primeiro lugar, apontava-se que já existia na cidade um curso que cumpria a função de formar professores de Ensino Religioso, sendo oferecido pelo Centro de Educação Superior [CES - mantido pela Ordem do Verbo Divino] com o título "Atualidades do Ensino Religioso". Em resposta, os defensores do curso na UFJF objetavam afirmando o caráter mais abrangente de sua proposta se comparada com o curso oferecida pela instituição de ensino superior católica. Concordante com isso, em 12/07/1977, publica-se uma reportagem na qual o monsenhor Miguel Falabella apoia o curso e vê como retrocesso sua proibição. "Para Falabella, o curso de Ciências as Religiões oferece muito como cultura histórica religiosa, ao contrário do de Atualidade de Ensino Religioso (ministrado no CES), em que a base é toda confessional (católica) e visa apenas a formação de professores para o primeiro grau" (Padre vê retrocesso na UFJF, Diário Mercantil, 12/07/1977, p.5). Além disso, o curso do CES era oferecido em período de férias, atingindo um público bem peculiar e diferente daquele almejado pela UFJF.

Numa folha, assinada pelo Pe. Jaime Snoek, há anotações sobre um encontro com D. Geraldo Penido em 28/04/1977(anexo 5). Nessa conversa, o eclesiástico diz ter apoiado o início do curso, mesmo sabendo o risco que havia para a ortodoxia. Ao ser indagado se apoiava ainda o curso, ele diz não ter condições de responder por não conhecê-lo. Mas ressalta que não aprecia que ex-padres (como era o caso do prof. Antonio Guglielmi) lecionem em "faculdades de teologia". Ao Ihe ser oferecido maior aprofundamento para conhecimento do curso, ele não demonstrou interesse. Segundo ele, não há curiosidade por parte do clérigo em saber o que se passa na UFJF16.

Em outro documento, intitulado "Pequeno relatório indicativo" (de 03/01/1978), no qual D. Geraldo transmite para Dom Juvenal Roriz (arcebispo na Arquidiocese de Juiz de Fora 1978-1990) informações relevantes sobre a arquidiocese, pode-se ler que mais do que interesse, havia tentativa de interferência por parte do arcebispo:

No início, encarei com simpatia o curso, mas posteriormente, ao verificar que aquilo estava se transformando num ninho de ex-padres e elementos contestatórios, retirei minha aprovação e tive a iniciativa de comunicar minha posição perante o Ministro da Educação no início do ano passado. Creio que, em 1978, o curso não mais funcionará com as mesmas regalias de antes ou simplesmente não existirá mais. A razão de minha

\footnotetext{
Apenas a título de curiosidade, neste mesmo ano de 1977, seria publicada a tradução da obra "Sobre Freud. Ensaio sobre interpretação" e, no ano seguinte, "O conflito das interpretações" de Paul Ricoeur. Ambas traduzidas por Hilton Japiassu. Hoje, é reconhecido por suas valiosas contribuições ao tema da epistemologia e ciência no Brasil.

16 No entanto, o registro que se faz dessa conversa na reunião do departamento soa um pouco mais positiva. "O prof. Jaime Snoek narrou detalhes de uma conversa com o Arcebispo de Juiz de Fora, D. Geraldo Maria de Moraes Penido, notando da parte do Sr. Arcebispo aceitação do curso, contanto que o mantivessem sempre informado a respeito do curso, sobre as disciplinas, etc. Resumindo: o Sr. Arcebispo gostaria de conhecer melhor o curso e seus docentes em nível de diálogo franco e amigo" (Ata Depto. de C. das Religiões, 07/06/1977).
} 
reserva era que nenhuma autoridade poderia ficar como fiadora da ortodoxia da doutrina ali ministrada: $\bigcirc$ reitor, não, porque não pode manifestar preferências religiosas, por ser a Universidade leiga, o arcebispo também não por não ter acesso autoritativo na Universidade(anexo 13)

Essa passagem é significativa. Ela reafirma o conteúdo da reunião com Snoek de quase um ano antes. Há um apoio inicial, mas que foi sendo enfraquecido. No entanto, nesse documento ficam mais claros os motivos que, basicamente, são dois. $O$ curso agregou pensadores que não se alinhavam com as perspectivas religiosas defendidas pela cúria. Por exemplo, há apoio de alguns ao uso de métodos contraceptivos, prática não endossada pela igreja católica (por exemplo, SNOEK, 1981, 1967)17.Portanto, alguns professores assumiram posturas "contestatórias" ou divergentes aos posicionamentos oficiais. Além disso, diferindo-se dos demais cursos ligados à religião - que até neste momento sempre foram ministrados nos seminários e sob o controle do clero - tem-se uma nova situação. É um curso que estuda religião, ainda com forte tonalidade teológica, mas que não se submete à autoridade religiosa. Portanto, não há nenhuma autoridade para manter o controle sobre o que era ensinado ali. Isso se deve justamente ao fato de que se ter um curso sobre religião numa universidade pública. Isso, como se nota, é motivo de preocupação e desconfiança por parte do líder religioso.

Essas linhas podem nos dar a ideia de como o debate se desenvolveu de maneira acalorada. Muitas vezes, envolvendo mais paixão do que razão. Mas, essas oposições tiveram papel formativo central: foram fundamentais para clarificar o lugar e as intenções do curso. $\bigcirc$ movimento de uma postura mais estritamente teológica para o argumento de um estudo amplo do fenômeno religioso é, em muito, devedor dessa necessidade de defesa da sua legitimidade. A pressão política exige resistência neste nível, mas também traz consequências para se pensar o objeto, o método, os objetivos e o que se faz em Ciência das Religiões. Por isso mesmo, política e epistemologia não podem ser radicalmente separadas. Elas, mesmo onde não parece, andam de mãos dadas.

Essas articulações são também evidentes na próxima fase do curso. As oposições, mesmo que não se manifestem tão abertamente, ainda persistem. Mas, agora, o debate se movimenta em torno da proposta de reformulação do curso iniciada em 1980.

\section{Um curso em busca de identidade (1980-1991)}

A suspensão do vestibular não suprimiu a discussão em torno da graduação em Ciência das Religiões. Com o argumento de que não se trata de propor um curso novo, mas de reformulação de um curso existente (mesmo que não mais reconhecido pelo MEC), o departamento dá prosseguimento aos debates. Esse movimento é justificado no projeto de reestruturação por um fator central: o crescente interesse na universidade brasileira em se estudar a religiosidade. Como evidência, o documento cita a fundação da revista Religião $e$ sociedade na Unicamp bem como o início do mestrado em "Ciência das religiões" na PUC de São Paulo. Diante desse novo contexto de abertura à tematização da religião para além do âmbito estritamente eclesiástico, julgou-se haver respaldo para propor a reorganização do curso. Afinal, num primeiro momento, ele poderia funcionar em caráter interno e sem vestibular, para, numa situação mais favorável, requerer o devido reconhecimento.

${ }^{17}$ http:/ / www.diversidadesexual.com.br/wp-content/ uploads/2013/04//aime-Snoek-art-1967.pdf (site visitado em 23/08/2018)

\section{8}


Nessa conjuntura, observa-se uma aproximação das Ciências Sociais, configurando-se uma concepção multidisciplinar de Ciência das Religiões. Nas controvérsias decorrentes da reformulação do curso, novamente é de fora que vem o impulso para o aprofundamento epistemológico. Diante desse paradigma multidisciplinar, a pergunta que se levantava é pela real necessidade de um curso exclusivamente voltado ao estudo da religiosidade. Se outras áreas do saber (história, sociologia, antropologia, filosofia, etc) podem tratar da religião, como justificar a pertinência de um curso dessa natureza? Como resposta, a linha argumentativa sustentava a necessidade de uma conjunção entre abordagem empírica da religião e seus elementos estruturantes. Vejamos por meio dos documentos como essa discussão se desenvolve.

Já no ano de 1979, a reformulação do curso dá seus primeiros passos. Para tanto, solicita-se ajuda do Instituto de Estudos de Religião (ISER) no Rio de Janeiro. Inclusive, contrariando o tom mais formal das atas, faz-se o seguinte registro: "Tomando a palavra, o prof. Domício Pereira Mattos apresentou a todos o parecer rápido que 4 elementos do ISER tiveram ao ler nosso currículo: "mas isto parece um curso de seminário!" disseram eles. Daí, concordaram todos na rápida e eficiente mudança do currículo" (Ata do Departamento de C. das religiões, 07/08/1979).

A reforma curricular propriamente dita se inicia em 1980. Tendo em vista as oposições sofridas no momento anterior, houve a preocupação do departamento em apresentar o esboço do projeto a lideranças religiosas locais, a fim de obter seu consentimento. Há manifestação do Arcebispo Metropolitano, Dom Juvenal Roriz de 14 de Maio de 1980. Ele diz ter tido a melhor das impressões sobre o projeto, exaltando como o fenômeno da religião é abordado a partir das mais diversas ciências. "Tive a melhor das impressões sobre o anteprojeto. Penso que a UFJF, ao dar à Religião o lugar que lhe é devido entre as ciências humanas, estará fazendo justiça a sua própria condição de universidade. A Religião é, com efeito, a mais profundamente humana das manifestações do homem" (Processo no. 10598/80, p. 30 - currículo curso Ciência das Religiões - reestruturação) ${ }^{18}$. Há também a manifestação de Dario Schaeffer, pastor luterano e de Domício Pereira de Matos, que era também professor do curso e escreveu em nome do Sínodo da Igreja Presbiteriana. Todas favoráveis ao projeto.

Das alterações feitas em relação ao currículo em vigor, destacamos as seguintes:

1) $O$ curso passou a ser dividido em três ciclos. O primeiro, maior deles, é composto por matérias interdisciplinares, com o objetivo de possibilitar compreensão mais abrangente do fenômeno religioso;

2) Há inserção de abordagem de tradições religiosas diversas, principalmente as abraâmicas;

3) No último ciclo oferece-se habilitação em campo específico, havendo a preocupação em se justificar o oferecimento de cada uma delas. $O$ cristianismo aparece por se tratar da religião de maior influência no Ocidente. Religiões no Brasil, área criada nessa reformulação e que resulta dessa aproximação com as Ciências Sociais, justifica-se pela

\footnotetext{
18 Em ata, consta também o seguinte registro. "O prof. João Fagundes Hauch pediu que se registrasse a visita que o Sr. Arcebispo D. Juvenal Roriz fez aos 10 de Outubro de 1978 e, fazendo-o nesta ata, acentuamos o interesse que o Sr. Arcebispo mostrou pelo curso, prometendo fazer o que the fosse possível pelo apoio ao mesmo. Demonstrou, outrossim, vontade de conhecer a cada um dos docentes e o espírito com que são lecionadas as diversas matérias do departamento pedindo uma cópia de tudo o que se referisse ao curo para que pudesse conhecê-lo melhor e apoiá-lo quando fosse necessário" (Ata do depto. de C. das Religiões, 06/03/1979).
} 
relevância para compreensão do contexto brasileiro. E, por fim, o Islamismo interessa por sua grande repercussão mundial. Aliás, não é a primeira vez que este tema do Islã aparece como objeto que deveria ser estudado.

O currículo dessa proposta de reformulação se estrutura do seguinte modo:

\begin{tabular}{|c|c|c|c|}
\hline $\begin{array}{lr}\text { Primeiro } & \text { Ciclo: } \\
\text { Orientações } & \text { gerais, } \\
\text { embasamento } & \text { e } \\
\text { metodologia } & \end{array}$ & $\begin{array}{l}\text { Segundo Ciclo: visão } \\
\text { panorâmica } \\
\text { religiões } \\
\text { humanidade }\end{array}$ & $\begin{array}{l}\text { Terceiro Ciclo: } \\
\text { habilitação em uma } \\
\text { da três modalidades } \\
\text { seguintes }\end{array}$ & Optativas \\
\hline $\begin{array}{l}\text { Português I } \\
\text { Estudo comparado das } \\
\text { religiões I } \\
\text { Filosofia da Religião I e II } \\
\text { Antropologia cultural II } \\
\text { Metodologia e técnica de } \\
\text { Pesquisa I e II } \\
\text { História das Ideias Políticas } \\
\text { I e II } \\
\text { História Contemporânea I, } \\
\text { Introdução à Psicologia, } \\
\text { Psicologia da Personalidade } \\
\text { II } \\
\text { Psicologia Social I } \\
\text { Psicologia da Religião I e II } \\
\text { Ética I e II } \\
\text { História da Filosofia I e II } \\
\text { Antropologia filosófica I e } \\
\text { II } \\
\text { Sociologia I, VI, VII, VIII, } \\
\text { IX } \\
\text { (Obs. O aluno é obrigado } \\
\text { a cursar apenas uma } \\
\text { dentre as sociologias) }\end{array}$ & $\begin{array}{l}\text { Estudo comparado } \\
\text { das religiões II, III e } \\
\text { IV19 } \\
\text { Introdução a } \\
\text { Mundo Bíblico I e II } \\
\text { História do } \\
\text { Cristianismo I, II, III } \\
\text { e IV }\end{array}$ & $\begin{array}{l}\text { Constituído de } \\
\text { habilitação em uma } \\
\text { das três modalidades } \\
\text { seguintes: } \\
\text { Cristianismo: } \\
\text { Cristianismo I, II, III e } \\
\text { IV; } \\
\text { Religiões no Brasil: } \\
\text { Religiões no Brasil I, } \\
\text { II, III e IV20; } \\
\text { Islamismo: Islamismo } \\
\text { I, II, III e IV. } \\
\text { Obs.: Ecumenismo } \\
\text { comum às três } \\
\text { habilitações }\end{array}$ & $\begin{array}{l}\text { Oferecidas pelo } \\
\text { departamento: } \\
\text { Cristianismo V, } \\
\text { VI, VII e VIII21: }\end{array}$ \\
\hline
\end{tabular}

(Processo no. 10598/80, p. 9-11 - currículo curso Ciência das Religiões - reestruturação)

19 O curioso é que, observando as ementas, as disciplinas de Estudo comparado das religiões têm pouco de estudo comparado. Elas se parecem mais com abordagem das tradições religiosas. Assim EC I trabalha religiões primitivas e questões de metodologia (mito, rito, Eliade etc); o EC II trata de budismo e hinduísmo; EC III Roma e Grécia; EC IV: religiões ameríndias (Incas, Astecas, Maias; Oceania e Austrália);

20 Religiões no Brasil I: Religiões ameríndias no Brasil; religiões afro-brasileiras; catolicismo na sua inteiração com essas religiões; RBIl: Africanos vistos por portugueses; sua vinda par ao Brasil; sincretismo; candomblé rural e macumba urbana; misticismo; sociologia do misticismo. Religião africana e ideologia de libertação; RBIII: Sobrevivências das religiões afro; protestantismo; messianismos e pentecostalismos; religiosidade popular; RBIV: espiritismo, maçonaria, positivismo, pitagorismo, extremo oriente no Brasil; cultura e religião em Juiz de Fora.

${ }^{21}$ Cristianismo II: Jesus histórico; Cristianismo III: eclesiologia; Cristianismo IV: Teologia moral; Cristianismo V: Deus de Israel; Cristianismo VI: Cosmovisão bíblica; Cristianismo VII: Milagre na Bíblia; Cristianismo VIII: Julgamento e condenação de Jesus.

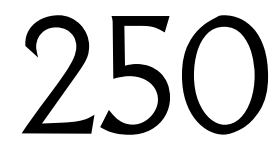


Outra alteração importante ocorre na justificativa do curso. No primeiro projeto, aquele de 1971, defendia-se a necessidade do departamento com base no caráter universalista da filosofia e da teologia e de sua importância na constituição das instituições de ensino superior mundo afora, tomando claramente por base o modelo europeu. Já na década de 1980, a justificativa acentua aspectos mais contextuais. É a relevância social do tema no contexto brasileiro que torna relevante o oferecimento de um curso dessa natureza. Essa percepção aparece, por exemplo, ao se alegar que o curso não possui caráter confessional: "O estudo do cristianismo, do islamismo e das religiões no Brasil, religiões sem dúvidas específicas, não são estudadas sob um critério confessional, mas sim dadas as influências cultural e sócioeconômica exercidas em nosso meio" (Processo no. 10598/80, p. 7 - currículo curso Ciência das Religiões - reestruturação). Ou seja, a reivindicação da relevância social e cultural assume lugar mais central do que possuía antes. Portanto, passa-se de argumentos mais gerais para mais próximos à realidade nacional. Pode-se inferir que essa mudança de postura é reflexo desse movimento de aproximação das ciências empíricas, principalmente C. Sociais.

Na caracterização do curso, pode-se captar a compreensão de C. das religiões que se desenha aqui:

\begin{abstract}
Compete a um curso de Ciência das Religiões estudar do ponto de vista fenomenológico, a religiosidade, essa atitude dinâmica de abertura do homem ao sentido radical (transcendente) de sua existência segundo P. Tillich. Nesse sentido de ser uma atitude e manifestação pessoal e comunitária, a religiosidade imprime a sua marca nas culturas. Essa é a razão porque a Ciência das Religiões tem despertado interesse crescente nas grandes universidades confessionais e não confessionais da Europa e dos Estados Unidos. A importância desse estudo interdisciplinar foi evocada também pelos dois conselheiros do CFE, Newton Sucupira e B.B. Bittencourt (Processo no. 10598/80, p. 7 - currículo curso Ciência das Religiões - reestruturação)
\end{abstract}

Dessa citação, destacam-se três aspectos. Em primeiro lugar, a fenomenologia é entendida como perspectiva ("ponto de vista" nos termos do documento) a partir do qual a religiosidade é abordada. Com isso, busca-se evitar abordagens reducionistas da religião. Fenomenologia aqui não é (apenas) método, como se estivesse em pauta a defesa de uma única metodologia na abordagem da religiosidade. Antes, como o próprio documento evidencia, a metodologia é interdisciplinar. Portanto, uma vez que inclui abordagem que se quer sistemática e empírica, com um objeto extremamente amplo, não faria sentido defender um monismo metodológico. Aliás, essa não me parece ter sido e nem ser atualmente a reivindicação daqueles que buscam na Fenomenologia da Religião um lugar para articular a interdisciplinaridade metodológica constituinte da C. da Religião. Não se trata de conceber a fenomenologia apenas como método, mas como perspectiva sobre o fenômeno religioso. Em poucas palavras, essa perspectiva busca compreender a religião a partir do ponto de vista do fiel para, então, elaborar categorias de compreensão, buscando compreender a religião a partir de um elemento religioso. Aliás, por isso o recurso à categoria "sagrado".

Dessa maneira, há preocupação em se indicar, por meio da fenomenologia da religião, um caráter mais sistemático e geral de compreensão da religião como tal. Aliás, para nos ater aos termos dos documentos, não se fala em religião propriamente dita, mas em religiosidade. Um das razões para essa opção parece ser indicar que não se trata apenas de abordar as instituições religiosas, mas a vivência religiosa que inclui aspectos institucionais, mas o ultrapassa em várias direções. Isso fica evidente pela referência que se faz a Paul Tillich 
(TILLICH, 1957): religiosidade seria aquilo que preocupa o ser humano de maneira última. Portanto, tratar desse tema implica em não apenas se restringir aos lugares e manifestações mais evidentes e dogmáticas da religião, mas tratar do ser humano existe enquanto levanta questões últimas de sentido.

Essa abertura ao sentido último, entretanto, não acontece abstratamente, mas na concretude da vida. É importante também se atentar que religiosidade não é simplesmente um assentimento intelectual a um conjunto de ideias, mas é entendida como atitude, uma espécie de comportamento que envolve o ser humano em sua totalidade. Essa atitude pode ser elaborada individualmente ou pode assumir contornos coletivos. Ela, portanto, se dá de diversas feições por meio de suas manifestações históricas, que também se constituem como objeto de preocupação dessa ciência.

Dessa maneira, está aqui subjacente a exigência de uma compreensão mais geral da religiosidade e, ao mesmo tempo, a lida com suas manifestações concretas, históricas e singulares. A referência a Tillich parece pertinente, uma vez que sua compreensão de religião amplia em muito o objeto. Entender religiosidade como estando articulada com perguntas de sentido último inclui no objeto da Ciência das Religiões fenômenos nos quais a religião não aparece de forma claramente reconhecível (símbolos, mitos, ritos, doutrinas). Aliás, é muito mais a atitude do que o conteúdo que determina a religiosidade. Enfim, há uma proposta que define um ponto de vista de abordagem da religião, que busca integrar elementos sistemáticos e empíricos e, por fim, emprega diversos métodos na tentativa de compreender a religiosidade22.

Percebe-se, nesse momento,a preocupação em se enfatizar o caráter não-confessional do curso. Nessa direção, o documento, para defender a objetividade dos estudos sobre religião e sua independência em relação aos credos, enfatiza mais o seu objeto o estudo da "manifestação religiosa", ficando de fora a religião de modo mais geral (Processo no. 10598/80, p. 7 - currículo curso Ciência das Religiões - reestruturação). É possível também pensar que isso se deva a algum descuido por parte de quem redigiu essa parte do documento.

O documento de reformulação do curso, ao menos em seu início, enfatiza a formação mais geral, destacando que o primeiro ciclo conta com maior número de créditos. Com intuito de legitimar o curso de Ciência das Religiões no seu caráter não-confessional acentua-se o papel das disciplinas que tratam mais indiretamente da religião. Vale ressaltar que, apesar desse ter sido o caminho escolhido, ele não é o único possível. Por exemplo, para destacar a cientificidade, poderia ter sido acentuada a metodologia de abordagem do fenômeno religioso ou sua abrangência. Aliás, essa articulação entre ponto de vista, objeto e disciplinas (método?), conforme exposto acima, parece-me bastante consistente.

Mas, a compreensão que se firma nesse período - de que Ciência das Religiões seria, na verdade, um ponto de encontro de diversas disciplinas (e não apenas metodologias) que se ocupam da religião - parece encaminhar a argumentação no sentido de se legitimar o curso recorrendo-se ao prestígio de outras áreas já estabelecidas e que, de alguma maneira, lidam com a religião. Assim, na tensão que se instaura entre a unidade de ponto de vista sobre o objeto e a interdisciplinaridade, este último polo acaba por se avolumar e se transforma em pluralidade disciplinar, afirmada como característica desse campo de estudos.

\footnotetext{
${ }^{22}$ Ainda que os documentos não indiquem nada mais substancial, é interessante observar que essa abordagem da ciência da religião como constituída de uma parte sistemática e outra empírica é bastante difundida. Essa divisão clássica na Ciência da Religião, estando presente desde seu início com F. Max Müller, permeando várias propostas. Aliás, essa divisão parece ser um dos poucos pontos pacíficos na história da ciência da religião (Müller, 1893, p.74; WACH, 1988, P.53S)
}

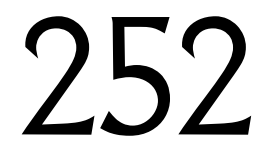


Se esse modus argumentativo busca imputar à $C$. das Religiões a seriedade acadêmica conquistada por outras áreas, ela acaba por trazer um problema, especialmente quando se pensa num curso de graduação: qual é a especificidade da abordagem do fenômeno religioso que justifica a existência de um curso dessa natureza? Aliás, é justamente essa a pergunta levantada pelo Prof. Lucas Marques do Amaral (Pró-reitor de Ensino e pesquisa). O seu parecer sobre a reformulação do curso reconhece a importância do estudo da religião (o que já indica um avanço em relação ao período anterior), mas pondera:

Podemos entender que este curso, denominado de Ciência das Religiões, possua objeto específico, que não deve ser considerado como uma questão acidental, resultando de interesses individuais de sociólogos, antropólogos, filósofos ou de qualquer área das ciências humanas. Mas, quanto ao método de análise científica, consideramos que o fenômeno religioso (e aqui entendemos religião como cultural e não como revelação) pode ser abordado por qualquer um dos métodos próprios das ciências sociais e, portanto, ficamos pensando se tal curso não deveria ser oferecido a nível de pósgraduação (Processo no. 10598/80, p. 36 - currículo curso Ciência das Religiões reestruturação) .

É curioso observar que o parecer menciona várias áreas do saber, com uma ausência importante: não faz referência à teologia. Aliás, o parecerista entende que o curso compõe o âmbito das ciências sociais. A partir dessa premissa, há crítica das disciplinas de cristianismo, uma vez que, a seu ver, elas seriam muito teológicas. Isso pode ser evidência do caminho que o curso seguiu. Ele se inicia muito próximo da teologia. Como tentativa de mostrar a legitimidade acadêmica, consolida-se o discurso de se abordar a religião das mais diversas perspectivas. Diga-se de passagem, é curioso que quando justamente há uma aproximação das ciências sociais, essa perspectiva disciplinar ganha mais força, ainda que inicialmente houvesse um lugar de destaque para a fenomenologia da religião como perspectiva.Mas, de todo modo, essa ênfase disciplinar mostra um limite, expressa na pergunta levantada por este parecer e, como observaremos, pelos subsequentes: o que caracteriza o próprio da $\mathrm{C}$. das Religiões? $\mathrm{O}$ que ela promove em sua abordagem da religião que outras áreas já não fazem ou não teriam condições de fazer? Qual sua contribuição peculiar a ponto de justificar uma graduação?

O caráter lacônico da resposta que se oferece a esse questionamento demonstra o embaraço causado pela pergunta. O departamento reconhece que: "Com razão o parecer levanta a questão da metodologia em Ciência das Religiões. Concordamos que Ciência das Religiões não é Teologia. Mas também não é Sociologia e sua metodologia não se identifica com "métodos próprios das ciências sociais" (Processo no. 10598/80, p. 40 - currículo curso Ciência das Religiões - reestruturação). Vale ressaltar que, em sua resposta, o departamento menciona duas áreas do saber que tiveram papel determinante na sua constituição: teologia e ciências sociais. Portanto, para além das proximidades, coloca-se também a necessidade de se estabelecer as diferenças. Mas, exatamente neste ponto, a resposta se torna vaga. Sobre isso é simplesmente dito: "A singularidade do fenômeno do Sagrado exige uma abordagem própria que é difícil de ser definida em poucas palavras." (Processo no. 10598/80, p. 40 - currículo curso Ciência das Religiões - reestruturação). Em seguida, menciona-se uma bibliografia em alemão e italiano sobre métodos em Ciência da Religião. Que dizer: a pergunta central não é respondida, afinal, o que está em questão não é a relevância ou complexidade do objeto, mas o que caracteriza a aproximação metodológica do curso que faz pleito de sua legitimidade.

Ainda, no sentido de esclarecer a aproximação que se faz do cristianismo, a resposta do depto. de Ciência das Religiões defende que a abordagem dessa tradição religiosa não éde teologia (no sentido que envolve compromisso com uma fé que conduz a uma práxis), mas sobre teologia.

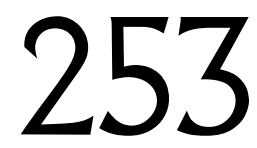


Em 10/06/1981, o projeto passa na reunião do Conselho de Unidade do Instituo de Ciências Humanas e Letras (ICHL). É eleita a profa. Helena Mendes Meirelles, das Ciências Sociais, como relatora. Em sua análise, ela requer maiores esclarecimentos, dos quais destacamos: 1) explicitar os objetivos do curso; 2) abordar a questão metodológica com maior clareza, inclusive explicitando as divergências metodológicas no interior das Ciências das Religiões e como isso repercute nos programas das disciplinas e nas aulas. E ainda,3) explicar porque a linguagem referente às ementas relativas ao Cristianismo soam mais como um estudo de teologia do que sobre teologia. Sobre o último tópico, é curioso que ao se tratar do Islã, as disciplinas mencionam expressamente teologia. Mas, o questionamento feito às disciplinas de cristianismo não se estendem às disciplinas dessa outra tradição religiosa; 4) por fim, o parecer solicita explicação para a elevada carga horária dedicada a disciplinas atinentes à tradição cristã (Processo no. 10598/80, p. 44- currículo curso Ciência das Religiões - reestruturação).

Em resposta, o Departamento redige um ofício datado de 18 de Agosto de 1981. Com relação aos objetivos, ele assinala a importância da religião na constituição da cultura, especialmente brasileira para, então, indicar os objetivos propriamente ditos. Diante da universalidade e importância do tema, "O curso de Ciência da Religião se propõe, pois, uma pesquisa sistematizada que congregue os elementos dispersos numa visão de conjunto" (Processo no. 10598/80, p. 44- currículo curso Ciência das Religiões - reestruturação p.46). Em outros termos, solidifica-se a perspectiva de ciência das religiões se constitui de maneira interdisciplinar (ou, talvez, pluridisciplinar), sendo sua função a sistematização das diversas abordagens do fenômeno religioso produzidas pelas outras disciplinas. $O$ seu caráter peculiar, portanto, não estaria em seu ponto de vista sobre a religião, nem mesmo na constituição de um método autóctone. Antes, estaria em buscar essa visão de conjunto, ou seja, a sistematização de abordagens múltiplas empreendidas pelos diversos saberes. No fim dessa parte, para comprovar a relevância do estudo da religião, menciona-se que há estudos na USP e na UNICAMP, no intuito de recorrer a uma autoridade para justificar o curso. Menciona-se também o curso de pós-graduação da PUCSP.

No entanto, novamente, o cerne do questionamento dizia respeito à metodologia. Tanto é assim que o ofício se demora nesse ponto. O primeiro passo no sentido de solucionar os problemas levantados é a inserção de uma discussão metodológica na disciplina Estudo comparado das religiões I. Há um elemento aqui que não pode ser ignorado. A pressão para uma discussão epistemológica vem de fora. Nesse momento, são justamente os pareceres que conduzem a essa reflexão. E, talvez mais no intuito de oferecer uma resposta imediata, adota-se essa solução. Os tópicos inseridos são:

1. História do estudo das religiões e do "fenômeno religioso"

2. A nova ciência da religião e sua metodologia.

3. A especificidade do estudo do fenômeno religioso: o sagrado.

4. O sagrado e sua interpretação em autores modernos: Van der Leeuw, R. Otto, M. Eliade e outros.

5. A significação polifacética do sagrado: como "real"; como "ser em si" e em suas manifestações simbólicas e míticas.

6. A independência do método de análise do fenômeno religioso.

7. A referência a disciplinas auxiliares na percepção total do fenômeno religioso.

8. O fenômeno religioso e suas encarnações no tempo e no espaço: as religiões.

Avançando para além dessa solução mais pontual, o ofício desenvolve uma discussão indicando como concepções metodológicas moldam o projeto do curso. Para tanto, indica

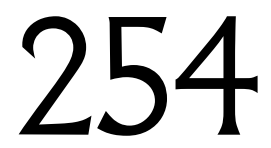


uma possibilidade metodológica que não é a adotada. $\bigcirc$ curso, tendo em vista a compreensão do fenômeno religioso, poderia desenvolver-se como história das religiões, focando nas interpretações sociológicas e psicológicas do fenômeno religioso. No entanto, não é isso que se pretende. Afinal, fazer história das religiões não é ainda ciência das religiões, uma vez que se restringe a uma mera descrição do fenômeno religioso. A outra alternativa, encampada pelo departamento, "valendo-se da contribuição dessas ciências" busca "concentrar a atenção em primeiro lugar sobre as estruturas específicas do fenômeno religioso, procurando compreender sua essência, seu sentido e sua mensagem" (Processo no. 10598/80, p. 44currículo curso Ciência das Religiões - reestruturação p.46). Em outros termos, as abordagens empíricas não se encerram em si mesmas, mas se configuram como ponto de partida para perguntas mais gerais, tendo em vista os elementos estruturantes da religião, a fim de desenvolver (nos termos de Eliade) uma morfologia da religião.Mas, além da essência, há outro patamar que se questiona quanto ao sentido da religião.

Para essa abordagem (que parte do empírico, passa pela estrutura da religião e chega ao seu sentido), são pontuados três passos, chamados de procedimentos. Em primeiro lugar, há o procedimento histórico. Aqui, a intenção é analisar como as religiões se manifestam concretamente no transcorrer do tempo. Esse é o passo inicial para que se possa chegar aos elementos estruturantes. Num segundo momento, há o procedimento fenomenológico. Se a história é atenta às particularidades e singularidades, a fenomenologia teria a função de encontrar os aspectos recorrentes, ou seja, a estrutura e o sentido dos dados coletados pela história. Aqui, "o que se intenta encontrar é a identidade do religioso, a sua 'mesmidade', em meio às variações históricas de suas formas" (Processo no. 10598/80, p. 44-currículo curso Ciência das Religiões - reestruturação p.46). Por fim, há o procedimento hermenêutico. Após se atentar às especificidades e à essência do religioso, é preciso interpretar para se alcançar a significação antropológico-existencial dos fatos religiosos. Em outros termos, não se trata apenas de levantar os dados e a estrutura da religião, mas de articular esses elementos com uma compreensão de ser humano, especialmente considerando sua abertura para a transcendência. Portanto,

Concluindo, dizemos que há uma característica própria ao estudo do fenômeno religioso. A característica específica desse estudo é o discurso, numa dimensão profunda, a um tempo fenomenológico e hermenêutico, sobre a Religiosidade Human. [sic].

Em suma, para afirmar a especificidade da abordagem do fenômeno religioso por parte da C. da Religião, reconhece-se a necessidade de se ir além dos aspectos meramente empíricos. Eles são ponto de partida para se alcançar a estrutura e o sentido da religião. Portanto, aquela divisão clássica da Ciência da Religião entre sistemática e empírica é reforçada.

E, por fim, o ofício ainda traz algo importante. Justamente no momento em que afirma a especificidade de abordagem do fenômeno religioso, há a menção do desejo de alteração do nome do curso: ele não mais deveria se chamar de Ciência das Religiões, mas de Ciência da Religião. Isso por duas razões. Em primeiro lugar, essa nomenclatura é consagrada na Alemanha (Religionswissenschaft). Além disso, com essa alteração pretende-se extirpar qualquer equívoco ou dúvida que possa haver sobre o caráter peculiar dessa ciência.

Apesar de sucinto, esse ofício toca em questões muito importantes, revelando certa oscilação epistemológica. Se de início o pêndulo tendia mais para a pluralidade e a dimensão empírica da religião, o questionamento sobre a peculiaridade do curso conduz à tentativa de integrar melhor aquilo que se anunciava: dimensão estrutural com a faces históricas da religião. A solução, como se vê, é bastante engenhosa. A história fornece o material bruto a partir de

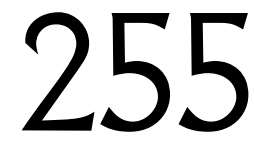


onde a fenomenologia pode encontrar elementos estruturantes (uma vez que recorrentes) e, por fim, a hermenêutica pode interpretar o sentido23.

Ainda em 1981, o processo é encaminhado ao reitor, prof. Márcio Leite Vaz. No entanto, em outubro desse mesmo ano, há uma parecer contrário ao curso emitido pela próreitora de Ensino e Pesquisa Therezinha Lopes de Assis. Em seu breve texto, ela menciona que não há autorização desse tipo de curso pelo CFE. Ainda, retoma o parecer negativo da CEPE 55/77, não considerando que esse mesmo parecer havia aberto a possibilidade de que 0 projeto fosse reapresentado. Por fim, refere-se ao Artigo $1^{\circ}$ do Decreto no. 86.000, de 13 de Maio de 1981 que proibia a criação de novos cursos nas universidades até Dezembro de 1982. Diante disso, ela sugere a continuidade do oferecimento das disciplinas que os professores do departamento disponibilizam em outros cursos da UFJF, bem como a ventila a possibilidade de criação de um curso "lato sensu".

Em resposta, Jaime Snoek redigiu um documento no qual retoma um longo histórico do curso. Sobre essa questão específica, o cerne do seu argumento está em que não se trata de criação de um novo curso, mas de reestruturação. $O$ curso já existe na sua modalidade livre (quer dizer, não tem diploma reconhecido pelo MEC). Diante dessa resposta, a pró-reitoria solicita parecer à comissão jurídica. No pedante parecer, que discorre mais sobre outras questões do que propriamente sobre a solicitação, ataca-se com força o positivismo. A universidade não é fábrica; não dever agir com preconceito em relação ao estudo do fenômeno religioso. No entanto, ele não entra no mérito próprio das questões legais aqui envolvidas, ainda que indique que não há nada que impeça seu oferecimento. Diante disso, a pró-reitora afirma a necessidade de se enviar o processo ao Conselho de Ensino, Pesquisa e Extensão (CEPE) para elaborar nova consulta ao Conselho Federal de Educação (CFE). Isso é feito em novembro de 1983. Em resposta, o CEPE entende que se trata de uma reformulação (e não criação de um curso), mas reconhece que esse pedido inicial de reformulação do curso se transformou no questionamento quanto à legalidade da sua existência $O$ processo retorna para o Departamento, principalmente solicitando-se que haja esclarecimentos quanto ao estatuto de curso não reconhecido pelo MEC. Após quatro anos de embates, a pasta com o processo se encerra aqui. Pelo visto, o fôlego para levar essa proposta de reformulação adiante também.

Desse período, cabe ressaltar que foi realizada a primeira semana de Ciência das Religiões, entre os dias 11 e 15 de Abril de 1983, mesmo como todos esses embates acontecendo. Os temas, mas principalmente os palestrantes,chamam a atenção:

As abordagens científicas do fenômeno religioso - Prof. Rubem Alves (UNICAMP);

As funções terapêuticas da religiosidade popular (pentecostalismo, religiões afrobrasileiras e outras) Renato Ortiz (UFMG);

Igreja e política - o caso polonês - Rubem Cesar Fernandes;

A religião como veículo da educação popular - Carlos Rodrigues Brandão (UNICAMP);

As comunidades eclesiais de base - uma igreja polarizada? Pedro Ribeiro de Oliveira CERIS/ ISER;

23É interessante a semelhança com procedimentos metodológicos propostos por Paul Ricoeur. Em $A$ simbólica do mal (escrito em 1960), propõe partir de uma fenomenologia (ao modo de Eliade). No entanto, pretende superar o aspecto meramente comparativista por meio de uma hermenêutica (interpretação) (Vide. RICOEUR, 2013, p. 370). Já em O conflito das interpretações, menciona três estágios. O primeiro, fenomenológico, aponta para uma comparação dos símbolos com outros símbolos. Num segundo momento, por meio da hermenêutica, ressalta-se o sentido dos símbolos. Por fim, por meio da reflexão, desenvolve-se uma filosofia a partir dos símbolos (RICOEUR, 1978, p.250-252). Mesmo que as diferenças sejam claras, é interessante observar também as coincidências.

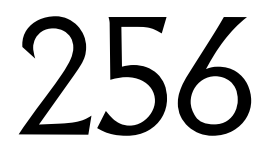


O protestantismo no Brasil. Reação ou mudança? Zwinglio Mota Dias;

Raízes históricas do sincretismo religioso - RiolandoAzzi (PucRio);

O Sobrenatural na teologia da libertação - Leonardo Boff (OFM - Petrópolis).;

O lugar do feminino nas várias experiências religiosas - Levy Lerverstein - Fundação

Ford/Iser(Ata do Departamento de C. da Religião, 09/11/1982).

Com relação ao curso propriamente dito, o tema volta a ser discutido logo depois. A proposta em 1987 era dar início, no ano subsequente, a um curso noturno que teria por objetivo complementar a formação dos discentes de outras áreas, visando aqueles que almejam uma compreensão mais aprofundada da cultura humana. Essa formação complementar não recebe o nome de especialização. Isso porque, pelo que transparece do documento, a intenção é implementar esse curso como ponte para futura abertura de vagas no vestibular. Tanto é assim que sua previsão era de dois anos de duração ou 1200 horas/aula. Ou seja, a proposta é criar condições para, em breve, se constituir um curso de graduação24.

O currículo proposta era constituído das seguintes disciplinas:

\begin{tabular}{|c|c|}
\hline $\begin{array}{l}1^{\circ} \text { Período } \\
\text { Filosofia da religião I } \\
\text { Psicologia da religião I } \\
\text { Sociologia da religião } \\
\text { Estudo comparado das religiões I } \\
\text { Introdução ao mundo bíblico I }\end{array}$ & $\begin{array}{l}3^{\circ} \text { Período } \\
\text { Religiões afro-brasileiras } \\
\text { Seitas religiosas I } \\
\text { Cristologia } \\
\text { Antropologia cristã I } \\
\text { Eclesiologia }\end{array}$ \\
\hline $\begin{array}{l}2^{\circ} \text { Período } \\
\text { Filosofia da religião II } \\
\text { História do cristianismo I } \\
\text { Antropologia cristã I } \\
\text { Estudo comparado das religiões II } \\
\text { Introdução ao mundo bíblico II }\end{array}$ & $\begin{array}{l}\text { 4. Período } \\
\text { Religiões afro-brasileiras II } \\
\text { Seitas Religiosas II } \\
\text { Cristologia II } \\
\text { História do cristianismo II }\end{array}$ \\
\hline
\end{tabular}

Nessa proposta curricular, a argumentação em favor do curso busca ressaltar a sua importância para que o discente possa ter uma visão mais ampla da cultura humana. Portanto, em sua justificativa, aparece a religião como dimensão da vida, importante para a compreensão do ser humano em geral. Já nas propostas, é perceptivel que as disciplinas mais formativas

\footnotetext{
${ }^{24} \mathrm{Na}$ ata de 20/05/1987, registra-se: "o objetivo do curso de Ciência das religiões seria o de oferecer aos alunos de outros cursos a possibilidade de complementar sua formação propiciando-lhes mais um horizonte de compreensão da existência e da própria cultura, abrindo as portas da universidade para pessoas e grupos interessados na compreensão mais profunda da religiosidade e de suas incidências nas outras dimensões da existência humana. Chegaria, portanto, a despertar e estimular nos estudantes o interesse pela pesquisa e reflexão nesta área da experiência existencial e cultural do homem, nem sempre tratada dentro do horizonte de sua identidade específica" (Ata do Depto. de C. das Religiões, 20/05/1987).
}

\section{7}


ficaram no primeiro período, ou seja, inicia-se com a abordagem da religião nas diversas disciplinas. Em termos de tradições religiosas,há forte presença de temas clássicos do cristianismo. Se na proposta anterior aparecia a alternativa de estudo do Islã, isso foi aqui abandonado. Em seu lugar, aparecem duas disciplinas específicas para tradições afro-brasileiras. Quanto a Seitas religiosas, uma vez que, até onde pude levantar, não há ementas para as disciplinas, não foi possível descobrir exatamente ao que se referem. De todo modo, o esboço de projeto prevê a contratação de professores para essas disciplinas e para sociologia, o que indica a carência de especialistas nessas áreas no corpo docente desse momento.

Pelo que foi possível averiguar, essa proposta não teve vida longa. Tanto é assim que já no ano de 1989, há registros de nova discussão em torno da proposta de um curso de graduação. Convoca-se uma reunião com pauta única de discussão em torno da montagem de um novo curso de graduação em C. das Religiões. Para tanto, segundo consta em ata, foram distribuídas cópias de um texto em alemão intitulado "O que é ciência da religião". Infelizmente, os registros não trazem o nome do autor deste texto. Mas, apenas mencionam que foi de grande relevância para o debate. Numa de suas inflamadas falas nessa reunião, 0 chefe do Departamento, prof. Antonio Guglielmi25 dá indícios de como se entendida a identidade do depto. Segundo consta em ata:

Não somos um departamento de Religião ou de Teologia; somos um departamento de Ciência, ou seja, de ensino e pesquisa científica do fato religioso, em sete áreas diferentes (história, filosofia, fenomenologia, sociologia, psicologia, antropologia e teologia). O objeto, pois, do nosso depto. como qualquer outro departamento, é o ensino e a pesquisa científica, em nível superior. Houve concordância de todos os presentes quanto à exposição feita sobre a identidade e objeto do nosso depto. (Ata do Depto. de ciência da religião, 25/10/1989).

Essa citação é importante e, de certa maneira, dá o tom do que vem a seguir. Reafirmase a identidade do curso em relação à teologia e, nesse caso, à religião. Com isso, a intenção é salientar que o departamento está comprometido com o fazer científico, portanto, não se tem em vistas funções de prática religiosa, promoção de determinada tradição religiosa e muito menos de formação de clero. Também não intenciona desenvolver reflexões sobre a cultura ou qualquer âmbito da experiência humana a partir da fé. Antes, o objetivo se constitui em torno do desenvolvimento de pesquisa do fato religioso. Há alteração também no modo como o objeto é nomeado. Não se fala mais da religiosidade como aquilo que constitui o objeto que confere unidade à ciência da religião, mas ao fato religioso. Emprega-se, portanto, uma terminologia de cunho mais sociológico, buscando uma coerência entre o objeto e o rigor científico afirmado. E, por fim, cabe ressaltar como uma perspectiva mais disciplinar se estabelece. Há unidade quanto ao objeto, mas as possibilidades disciplinares e metodológicas de abordagem se diversificam.

Em relação à proposta anterior, a fenomenologia da religião é entendida aqui como um método ou disciplina de abordagem do fato religioso e não mais como uma perspectiva. Dessa maneira, ela não é considerada mais como aquilo que concede um ponto de vista sobre a religião e que pode se desdobrar em variadas abordagens metodológicas, mas ela mesma é reduzida a um campo disciplinar que estabelece seu modo próprio de abordagem, ou seja, como método. Com isso, a articulação que se pretendia entre as singularidades e particularidades levantadas pelas abordagens empíricas e as mais gerais (feitas pela

25Para resumida biografia, cf. o texto de Pe. José Artulino Besen em http://pebesen.wordpress.com/padresda-igreja-catolica-em-santa-catarina / padre-antonio-guglielmi-\%E2\%80\%93-um-estudioso / 
fenomenologia e pela hermenêutica) se não é perdida, no mínimo, se enfraquece. Nessa nova elaboração, mais peso é dado para diversas aproximações do mesmo objeto. E mais. Essas diversas abordagens não são descritas em termos metodológicos, mas a partir de seus respectivos campos disciplinares (filosofia, história, antropologia etc) 26 .

Um dado inquietante é que após todos concordarem que a unidade do curso está em seu objeto, reconhecendo a área como visão de conjunto de outros campos disciplinares, na reunião subsequente, realizada em 04/12/1989, surja sobre a mesa a proposta de alteração do nome do departamento para Ciência da Religião. Isso em nada contradiz o singular de "religião", afinal, é aqui que reside certa unidade sobre a qual repousa a identidade do departamento. No entanto, se a Ciência da Religião é articulação de diversos outros campos disciplinares, qual a razão de se empregar "Ciência" no singular? Não seria mais coerente com essa perspectiva retomar a primeira proposta feita pela CFE e empregar "Ciências"? Os documentos não deixam clara a razão dessa opção27. No entanto, pode-se supor que ela se deve pelo impacto que textos da área escritos em alemão tiveram no departamento. Em todas as controvérsias epistemológicas (como, por exemplo, em torno do método na reformulação do curso em 1980), quando se cita bibliografia há muitas referências de textos de língua alemã e, em menor escala, em francês e italiano. No início da reunião anterior, como se observou, discutiu-se um texto traduzido do alemão com o título "O que é ciência da religião". Nessa vertente, o termo empregado é Religionswissenshaft (Ciência da religião)28. Assim, uma explicação plausível para essa opção parece estar na influência dessa tradição europeia nos professores à época.

Em termos práticos, essa reunião de 25/10/1989 também delibera importante decisão: "Todos ficaram concordes que o depto. deve envidar todos os esforços para montar e tentar, novamente, a aprovação do curso de graduação em Ciência da Religião. Foram feitas várias sugestões interessantes, entre as quais merece destaque a que foi feita pelo prof. Jaime Snoek, de se criar, como fase inicial, um curso de Especialização em Ciência da religião" (Ata do Depto. de ciência da religião, 25/10/1989). Em termos concretos, o departamento não perde de vista a graduação. No entanto, para atingir esse objetivo último, a estratégia é, inicialmente, constituir um curso de especialização. De certa maneira, essa alternativa já vinha se desenhando. Nos debates em torno da reformulação da graduação na década de 1980, havia a sugestão da constituição de um curso lato sensu. Posteriormente, a proposta de um curso

26 É no bojo dessa compreensão que se pode entender contribuições posteriores ao debate epistemológico como sustentada por Camurça, que afirma: “Desta forma, postulo então, outra perspectiva para as Ciências da Religião, em que as disciplinas das Ciências Humanas que as compõem seriam resguardadas no exercício pleno de sua autonomia teórico-metodológica, em torno de uma área (inter)disciplinar na qual o interesse comum dessas ciências seria a religião como tema"(CAMURÇA, 2008, p.61).

27 Cumpre lembrar que essa não é a primeira vez que essa discussão quanto ao nome do departamento aparece. Em um breve histórico, em sua fundação, é chamado de Ciências das Religiões. Em 1969, já há uma discussão para que o nome adotado seja Ciência das Religiões, o que se consolida nas atas a partir de 1974. No entanto, em 28/04/1981, Antonio Pedro Guglielmi levanta uma discussão nome correto do curso seria Ciência das Religiões ou Ciência da religião. Como decorrência, no projeto de reformulação do curso de 1980, já há a manifestação para a adoção da nomenclatura Ciência da Religião, o que viria a acontecer somente em 1989.

${ }^{28}$ Ciência da Religião (Religionswissenschaft) remete à tradição dos Países Baixos e da Alemanha, sendo associada com o surgimento da área e a busca de uma unidade, tanto epistemológica como temática, no estudo da religião. Por sua vez, a expressão Ciências das Religiões ressalta a pluralidade de métodos e enfatiza as tradições religiosas como objeto, sendo uma tradução possível para ReligiousStudies. E, por fim, Ciências da Religião, nome mais recorrente no Brasil, remete à tradição francesa das Sciencesdesreligions, que, ao menos em França, é herdeira das ciências sociais da religião.

\section{9}


noturno em 1987, ainda que não reconhecesse formalmente esse nome, na prática, se configuraria como um tipo de especialização. Então, em setembro de 1990, projeta-se o início da especialização para 0 ano seguinte. A estrutura curricular adotada segue a divisão disciplinar, contemplando cada uma das sete áreas: Antropologia da religião, psicologia da religião, fenomenologia da religião, filosofia da religião, etc.

Se a intenção inicial era que a especialização funcionasse como ponte para o estabelecimento de uma graduação, os caminhos levaram para outra direção. Já em 1992, as atas relatam discussões em torno da formação de um curso de mestrado29. A partir desse momento, o interesse pela graduação se dissipa, uma vez que o foco passa a ser cursos de pósgraduação. Com a implementação da pós-graduação strictu sensu, a especialização não é suspensa, mas passa cada vez mais a se conformar em vistas à pós-graduação. Uma vez que o objetivo desse texto é a análise dos projetos de graduação, não abordaremos esse momento do surgimento e consolidação da pós-graduação, ainda que reconheçamos sua importância.

Mas, antes de saltarmos para 2011, duas observações. É digna de nota essa incansável luta para o estabelecimento de um curso de graduação que marca o departamento desde os fins dos anos de 1960 até os anos de 1990. Sob as mais variadas formas, a questão sempre reaparece. Para além das querelas institucionais, os embates acabam trazendo indagações que impactam a reflexão epistemológica. Portanto, se elas acabaram retardando o estabelecimento de um curso de graduação, tiveram importante papel de conduzir reflexões teóricas em torno do curso, sua metodologia, objetivos e objeto. Contribuíram também para o seu amadurecimento.

Ao lado disso, o tema do ensino religioso é outra constante. Por mais que estrategicamente em certos momentos tenha se dito que a formação de professores não era objetivo do curso, o tema sempre reaparece. Essas referências indicam dois modos de atuação.

Pelas atas, o prof. Wolfgang Gruen se mostra bastante ocupado no sentido de defender e implementar um ensino religioso não confessional durante da década de 1970. Já em 1975, defende a necessidade de uma teoria do ensino religioso no Brasil, que o diferenciasse da catequese. Inclusive, em 1980, ele chega a esboçar como deveria ser uma disciplina de Metodologia do Ensino Religioso (Anexo 14). Menciona-se também que ele desenvolveu um estudo sobre o ensino religioso nas escolas a fim de pautar o pedido da licenciatura C. das religiões em 1973 (Ata do Depto. de C. das Religiões, 04/10/1974). Há, por fim, atuação em instâncias do estado de Minas Gerais (em reuniões no Conselho estadual de educação e na Assembleia Legislativa do Estado de Minas Gerais) bem como do governo federal30.

Com sua aposentadoria em 1981, as ações em torno do Ensino Religioso se tornam mais locais, visando tratar da questão na cidade de Juiz de Fora. Elas também tendem a se restringir a atuação em cursos de formação para professores, perdendo aquela dimensão mais institucional. Esses cursos ora eram solicitados pela secretaria do munícipio, outras vezes a iniciativa partia do próprio departamento. De todo modo, é interessante observar que essa

\footnotetext{
29 "Debatendo sobre o projeto de mestrado, os professores do Departamento de Ciência da Religião decidiram concentrar esforços para levá-lo adiante imediatamente. Foram sugeridas, provisoriamente, duas áreas de concentração - "Diálogo Interreligioso" e "Razão e Religião". O professor Luiz Bernardo Leito de Araújo foi designado coordenador do Projeto" (Ata Depto. de Ciência da religião, 07/04/1992).

30 As referências que pautam essas conclusões podem ser encontradas nas atas do Depto. de C. das Religiões, 4/10/1974; 14/03/1975; 17/04/1979; 21/02/1981 e 29/09/1981.
} 
prática, apesar de não ser sistemática, não foi interrompida nem mesmo com o início da especialização e do mestrado31.

\section{A implementação do curso de graduação. Um curso em busca de consensos mínimos (2011- )}

Em 2005, sob o governo do presidente Lula, O MEC (Ministério da Educação e Cultura) inicia o projeto de reestruturação das universidades federais denominado de REUNI. Além da criação de novas universidades federais, o programa previu o investimento em infraestrutura e expansão das universidades já existentes, expansão que implicou no aumento de vagas em cursos já existentes bem como a criação de novas graduações. Desse modo, em 07/10/2007, o colegiado do Departamento de C. da Religião da UFJF decide aderir ao REUNI, o que implicou em se pensar a graduação em Ciência da Religião, tanto no modelo de bacharelado (que visa, principalmente, a formação de pesquisadores na área de religião) como da Licenciatura (cujo objetivo primordial, ainda que não exclusivo, é a capacitação de professores de Ensino Religioso)32.

A decisão pela oferta da licenciatura se pautou pela necessidade de profissionais habilitados em trabalhar o tema da religião na escola, principalmente na escola pública UFJF, processo 230701.011960/2011-28). Além da legislação nacional, que assegura aos estudantes o direito de acesso a esse conhecimento, o Decreto estadual 44138 de 27/10/2005, em seu Art. $5^{\circ}$, diz que o exerć́cio da docência do ensino religioso na rede pública estadual de ensino de Minas Gerais deve contar, preferencialmente, com profissional que possua "I - conclusão de curso superior de licenciatura plena em ensino religioso, ciências da religião ou educação religiosa". Nesse sentido, a licenciatura em Ciência da Religião surgiu com o propósito de atender à demanda por profissionais com a devida formação para assumir estas aulas.

Além disso, notou-se a necessidade de profissionais que tenham domínio sobre o tema da religião a fim de lidar com esse espinhoso tópico no ambiente escolar ou fora dele. Para além da sala de aula e das aulas de Ensino Religioso, a religião está presente na comunidade escolar. Na maioria dos casos, ela é fonte de violência e causa de intolerância. Não somente entre os alunos, mas também por parte dos professores, pais, funcionários, gestores etc. No caso específico da região de Juiz de Fora, seguindo a tendência nacional, passou-se de uma expressiva presença do catolicismo para crescente número de alunos pentecostais e neopentecostais. Essa transformação tem acarretado inúmeros conflitos, diante dos quais muitos professores e gestores não sabem como agir, sendo de fundamental importância a presença de pessoas capacitadas no entendimento dos códigos religiosos e com sensibilidade para enfrentar esse novo quadro. Além do mais, a região de Juiz de Fora conta com expressivo contingente de Espíritas Kardecistas (quase 6\% - triplo da média nacional), o que acaba, de certa maneira, se refletindo na escola. No entanto, os conflitos mais recorrentes acontecem envolvendo pentecostais e neopentencostais.

Uma vez que este curso de graduação é uma novidade para a região e se preocupa em tematizar a presença da religião na escola, atualmente há um número expressivo de acadêmicos que estão cursando sua segunda (ou até mesmo terceira) graduação. Em muitos casos, são

${ }^{31}$ As referências que pautam essas conclusões podem ser encontradas nas atas do Depto. de C. das Religiões, 08/11/1983; 01/12/1992; 22/12/1992; 24/10/1994; 08/05/1995.

32 Muitas das informações abaixo foram retiradas do Projeto Político Pedagógico do curso. A fim de evitar excesso de notas, me furtei de fazer todas as referências. De todo modo, o PPP pode ser encontrado integralmente no site do curso: http:/ / www.ufff.br/graduacaocre /

\section{1}


professores da rede pública, atuando ou tendo interesse no tema da religião, e que encontram no curso a oportunidade de aprimoramento tendo em vista a contribuição e a intervenção mais efetiva na escola, numa perspectiva que valoriza a diversidade e aprende a conviver com ela. Isso é muito importante. Afinal, cabe ressaltar que as escolas municipais de Juiz de Fora, até a data presente, não oferecem a disciplina Ensino Religioso. É ilusão, entretanto, imaginar que simplesmente não oferecer a disciplina é o suficiente para que a religião não esteja presente.Por consequência, um dado que chama a atenção é que a graduação em C. da Religião possui a mais alta média de idade da universidade: 43 anos 33 .

A estrutura curricular do curso se divide em dois momentos, denominados de primeiro e segundo ciclo ${ }^{34}$. No primeiro ciclo, o educando inicia o curso no Bacharelado Interdisciplinar em Ciências Humanas $(\mathrm{BACH})$, que tem por objetivo central conceder ao estudante formação humanística abrangente. Nesse momento, ele tem contato e aulas com disciplinas das áreas de C. Sociais, Filosofia, Turismo e Ciência da Religião. O gráfico abaixo ilustra bem esse modelo, adotado também por outros institutos da UFJF que aderiram ao REUNI:

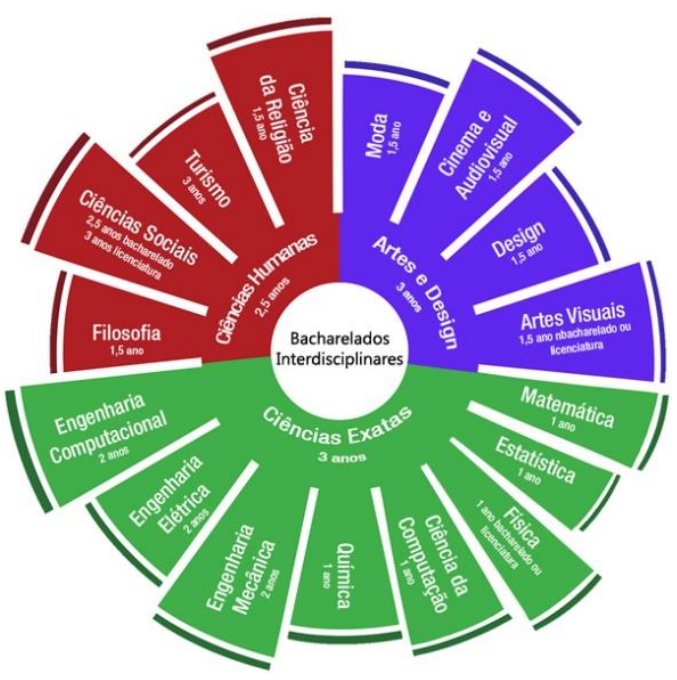

Ao iniciar o primeiro ciclo, o discente ainda não precisa optar por uma carreira específica, mas faz um curso de formação geral em ciências humanas. Ele tem oportunidade de cursar disciplinas oferecidas por vários departamentos do Instituto de Ciências Humanas para então, com maior maturidade e consciência, poder optar por uma carreira apenas no $5^{\circ}$. Período do curso.

Assim como outros departamentos, a CR também oferece disciplinas nesse primeiro ciclo, quais sejam: Filosofia da Religião I e II, Sociologia da Religião, Antropologia da Religião, Psicologia da Religião, História das Religiões, Estudo Comparado das Religiões I e II e Fenomenologia da Religião. Cabe ressaltar um traço comum a essas disciplinas. Elas privilegiam a interface do estudo da religião com outras áreas do saber, de modo que o discente (inclusive aquele que não pretende seguir na carreira de Ciência da Religião) tenha oportunidade de

\footnotetext{
33https: / / www2.ufff.br / noticias / 2017 / 06/20/aos-72-anos-aluna-mais-idosa-da-ufff-cursa-terceira-graduacao / (site visitado em 23/08/2018)

34 Para abordagem de pressupostos que norteiam o projeto, consultar HUFF; PORTELLA, 2012, p. 433-456. (http:/ / numen.ufff.emnuvens.com.br/numen/article/viewFile/1659/1454)
} 
conhecer como determinados saberes abordam o tema da religião. Entende-se que esse tipo de enfoque é o mais adequado para um curso que pretende ser de ciências humanas, oferecendo uma formação mais genérica. Além do mais, garantem-se abordagens mais autóctones da Ciência da Religião em disciplinas como Fenomenologia da religião e Estudo comparado das religiões I e II.

Vale observar que esse primeiro ciclo, na verdade, retoma certa tendência presente nos projetos pedagógicos anteriores. Em todos eles, observou-se a existência de uma formação básica a partir da exploração das diversas abordagens da religião. Em termos de organização prática, com o início da graduação, o que se fez foi transferir as disciplinas da especialização para esse primeiro momento do curso.

Como já observado, o discente tem de, no quinto período, optar por um curso no segundo ciclo. Isso implica que, no quinto período, além de redigir um TCC para concluir essa primeira etapa, ele tem de cumprir as disciplinas específicas atinentes à área que pretende seguir. Por exemplo: se o discente optou por cursar C. Sociais, há um conjunto de disciplinas dessa área que são obrigatórias quando ele chega ao quinto período de curso.

No caso de Ciência da Religião, o discente tem de cumprir as seguintes disciplinas: Introdução à Ciência da Religião; Teorias da Religião; Linguagens da Religião; Religiões no Brasil; e, Diálogo Inter-religioso. Se no momento inicial desse primeiro ciclo, o discente tem contato com disciplinas que exploram a abordagem da religião por saberes das ciências humanas, entendendo como é possível tratar o tema da religião de uma perspectiva acadêmica, no $5^{\circ}$. Período, ele tem dispõe de discussões teóricas e metodológicas específicas da área de Ciência da Religião. Esse é um dado novo nesse projeto pedagógico: questões teóricometodológicas ganham maior importância na formação do egresso, o que se evidencia na constituição de disciplinas específicas para isso. A intenção com elas é munir o egresso com ferramentas teóricas e metodológicas que o possibilitem pensar a religião a partir de sua especificidade, reconhecendo a pertinência e os limites de uma área de estudos denominada de Ciência da Religião.

Desse modo, há um entendimento de que o formado em Ciência da Religião deve ir além da acepção de que se trata de um lugar de encontro de pesquisadores com formações disciplinares as mais diversas e que tem por elemento comum o estudo da religião. Sem anular ou recusar a riqueza que as diversas áreas das ciências humanas trazem para se pensar e ensinar sobre a religião, especialmente as contribuições metodológicas, busca-se refletir sobre o que se constituiria a singularidade da abordagem da ciência da religião em comparação com outras aproximações. Essa singularidade não se dá apenas por exclusão, mas também por assimilação, apropriação e, porque não, antropofagia.

Por fim, a partir do $6^{\circ}$ período tem início o curso específico de Ciência da Religião (denominado de segundo ciclo), sendo composto por três eixos. Cada eixo, por sua vez, abarca núcleos. Os núcleos são formados de disciplinas. Em cada núcleo o discente deve cumprir um número mínimo de disciplinas para poder se concluir o curso. Sendo assim, não se propõe uma grade curricular fechada. $O$ próprio discente vai construindo o curso segundo seus interesses. Por outro lado, tomou-se a devida precaução para que o discente não se forme sem atender a alguns temas que se julgou fundamental para sua formação. Por isso, a exigência de creditação mínima nos núcleos. A grade curricular completa segue nas tabelas abaixo:

\begin{tabular}{|l|l|}
\hline Primeiro Ciclo & Disciplinas específicas (5º período) \\
\hline Filosofia da Religião I e II & Introdução à Ciência da Religião \\
Sociologia da Religião & Teorias da Religião \\
Antropologia da Religião & Linguagens da Religião \\
\hline
\end{tabular}

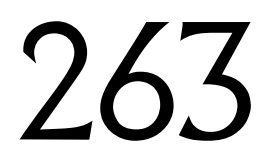


Aspectos históricos e epistemológicos da Ciência da Religião no Brasil

Psicologia da Religião

História das Religiões

Estudo Comparado das Religiões I e II

Fenomenologia da Religião
Religiões no Brasil

Diálogo Inter-religioso. 
Segundo Ciclo

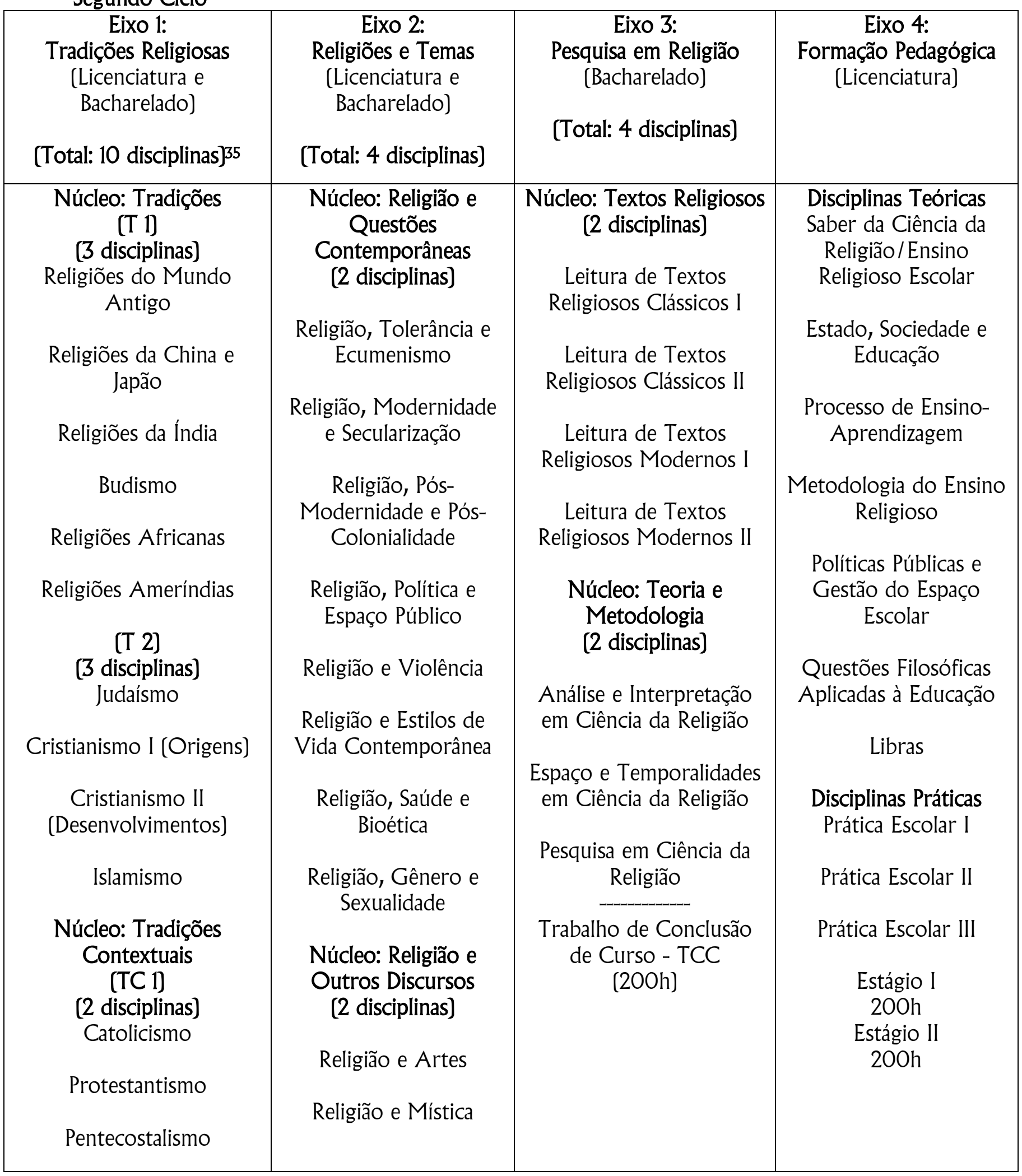

35 Número de disciplinas a serem cursadas pelos discentes em cada Núcleo.

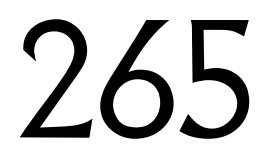




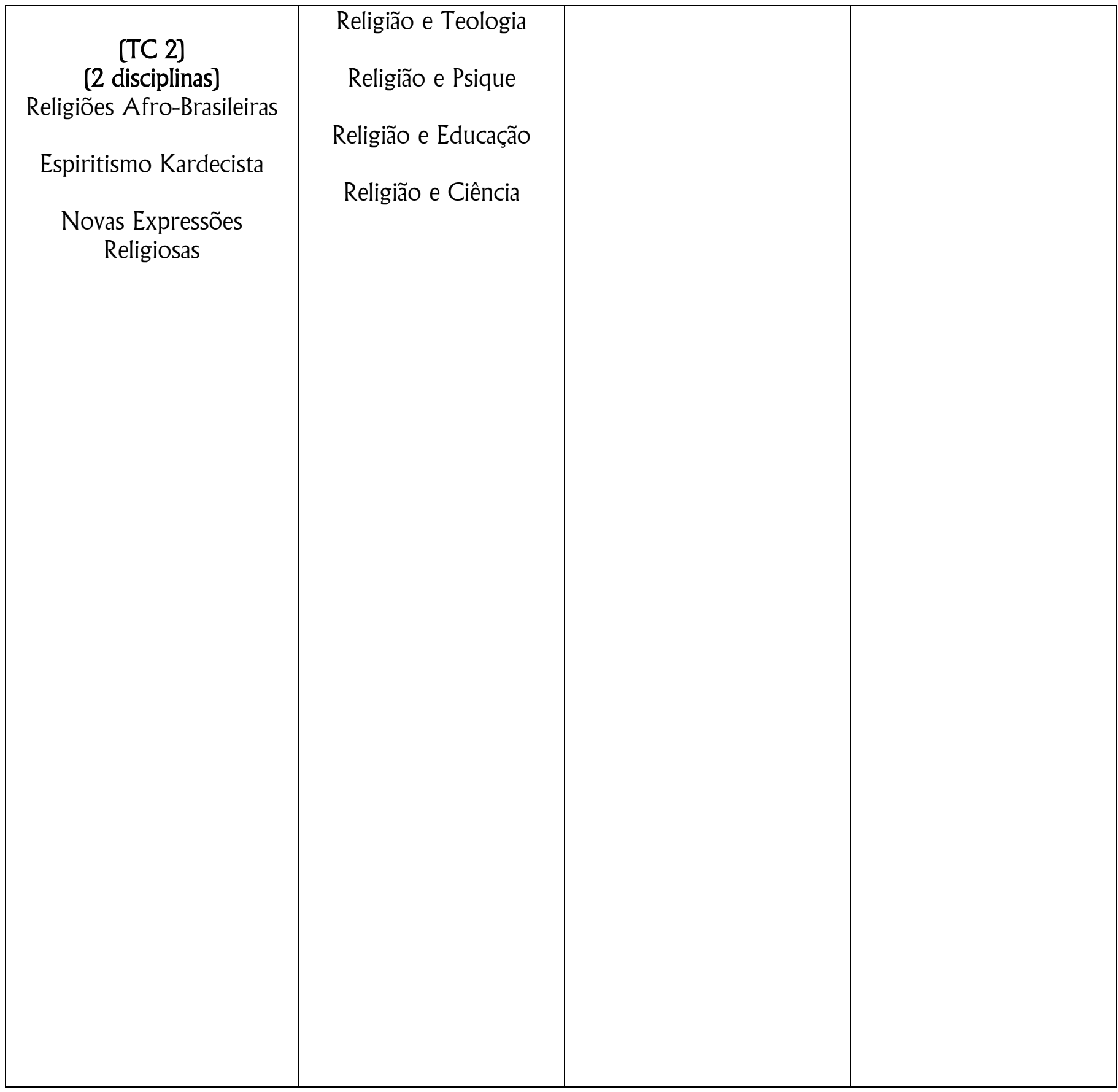

O eixo Tradições Religiosas, como é explícito na sua estruturação, visa fomentar uma postura compreensão as mais diversas tradições religiosas. Ele se inicia com manifestações religiosas menos comuns na nossa realidade sociocultural, passando pelas religiões monoteístas para, por fim tematizar as tradições mais expressivas no contexto nacional. Já o eixo Religião e Temas, por sua vez, diz respeito às análises sobre como pensar a religião em face de questões específicas e atuais, trazendo discussões candentes e complexas para a análise da religião.○ eixo Formação Pedagógica, tem por intenção, em suas disciplinas teóricas e práticas, a formação 
necessária à constituição de um profissional que terá como função trabalhar com a religião no contexto escolar. Já o eixo de pesquisa busca munir o egresso de ferramentas e conhecimentos sobre pesquisa científica.

Em resumo, a estrutura do curso é a seguinte: em primeiro lugar, o discente tem contato com o estudo da religião na interface com outros saberes. Num segundo momento, concentra-se em questões teórico-metodológicas específicas da Ciência da Religião. Por fim, de maneira concomitantemente, trata-se de temas e de tradições religiosas e sua transposição para o ambiente escolar ou da pesquisa científica em Ciência da Religião.

A preocupação central é a que os egressos entendam sobre o tema da religião e que se sintam habilitados em lidar com ele no contexto escolar de maneira criativa, contextualizada, crítica e compreensiva. Para aquele que optaram pelo bacharelado, que saiam se sentindo aptos a desenvolver pesquisas na área de religião. Sendo assim, há um cuidado de que eles tenham formação mais ampla, discussão epistemológica e conhecimentos sobre as diversas tradições religiosas e temas contemporâneos.

Considerando comparativamente com a primeira proposta do curso, elaborada cerca de quarenta e cinco anos antes, é importante observar um aspecto. $O$ objetivo do curso é ainda o de oferecer a possibilidade de uma abordagem sistemática e aconfessional do fenômeno religioso. No entanto, é clara a profunda alteração que se processou nessas décadas, especialmente no que concerne ao significado de aconfessional. Se na conturbada década de 1960, isso era entendido de modo exclusivamente metodológico, privilegiando a abordagem crítica de conteúdos atinentes à tradição cristã, o aconfessional é complexificado no que diz respeito ao seu objeto. $\bigcirc$ reconhecimento da diversidade religiosa que marca o contexto atual fez com que se mantivesse a abordagem acadêmica dos conteúdos, mas conduziu à ampliação das tradições religiosas e dos temas contemplados. O cristianismo é tratado no curso, reconhecendo-se nessa tradição religiosa aquela que fornece importantes quadros de referência para o Ocidente. Mas, se intenta ir além dessas fronteiras considerando compreensivamente outras manifestações religiosas.

Vale também registrar a inserção de disciplinas teórico-metodológicas da Ciência da Religião Ainda que não haja unanimidade entre o corpo docente sobre questões epistemológicas, é significativo o desenvolvimento de reflexões sobre esse tipo de temática com as demandas da graduação. Mais do que formar cientistas sociais da religião, filósofos da religião, teólogos, etc. essas disciplinas têm se revelado como espaço para se pensar o que significa ser cientista da religião inserido num contexto plural ou tendo em vista a atuação como professor de Ensino Religioso na escola pública laica.

\section{Conclusões}

Com o foco nos cursos de graduação e a pergunta compreensão do que se entende por Ciência da Religião, deparamo-nos com o seguinte quadro. Na sua primeira proposta, o curso da UFJF revela certas sobreposições com a teologia. No entanto, chama a atenção como de uma maneira relativamente rápida, as discussões epistemológicas vão assumindo centralidade, inclusive a percepção de que caberia a essa modalidade de curso a formação de professores de Ensino Religioso. Ainda que esse avanço não se reflita nas propostas curriculares. Pressionado por ganhar legitimidade na universidade, na década de 1980, o curso se alinha com as Ciências Sociais, incorporando vários de seus temas e referenciais. Essa alteração gera maior interesse por temas contextuais, especialmente pelas religiões no Brasil. Além disso, a percepção da Ciência da Religião como "visão de conjunto" sobre a religião ganha prestígio, estando esse entendimento no germe da criação de um curso de especialização na década de 1990. Em 2011,

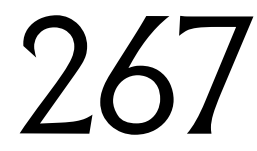


com o novo projeto e implementação do curso, é clara a incorporação deste último modelo num primeiro momento, mas sendo acrescentadas reflexões teórico-metodológicas da CR que, em grande parte, tentam pensar o aspecto peculiar da área frente a outros campos do saber, buscando consensos mínimos. Também neste momento, há ampliação das tradições religiosas contempladas.

Além disso, outro aspecto que parece ser recorrente é que o impulso para que as discussões epistemológicas sejam feitas ou aprofundadas acaba sempre vindo de fora. Ao menos no caso estudado, são as contestações que forçam os docentes a aprofundarem temas como a relação entre Ciência da Religião e teologia, a pergunta do método frente à pluralidade disciplinar ou mesmo a busca de consensos mínimos. Nesse sentido, é interessante como esses embates auxiliam no amadurecimento da proposta, mas sempre motivada por fatores externos.

Por outro lado, a história desse curso mostra uma dinâmica interessante: ele nunca parece se sentir completo e realizado. Sempre se está em busca de alguma coisa: em busca de legitimidade institucional, em busca de identidade ou em busca de consensos mínimos. Ao contrário do que pode parecer à primeira vista, isso não é algo negativo. Afinal, é por meio dessas incessantes buscas e crises que os projetos são implementados. É esse sentimento de incompletude que o faz ir adiante.

Não poderia encerrar esse texto sem destacar o papel do professor Jaime Snoek (19202013)36. Mesmo que durante todo o tempo em que esse redentorista holandês foi professor da UFJF, tenha permanecido no Depto. de Filosofia, suas contribuições extrapolam em muito esse campo. Aliás, ele é responsável pela fundação e estruturação de vários cursos na universidade. Mas, de maneira especial no momento em que havia forte intenção de fechar o curso de $C$. da Religião no final da década de 1970, ele se mostrou uma liderança fundamental. Pelos documentos, percebe-se alguém atuando junto às diversas esferas institucionais na defesa do curso. Do mesmo modo, as atas deixam entrever importante inserção entre os colegas, além de toda erudição e articulação acadêmica. Enfim. Ao menos pelos documentos, percebe-se que a existência atual do departamento deve muito a ele. Fica aqui um póstumo, mas justo reconhecimento.

\section{Referências.}

\section{Documentos}

\section{Processos das propostas de graduação}

Processo 3048/71 - Criação do curso de Ciências das Religiões

Processo no. 10598/80 - currículo curso Ciência das Religiões - reestruturação

Processo 230701.011960/2011-28 - Graduação em Ciência da Religião, UFJF

\section{Atas}

36http:/ / www.ufjf.br/ secom/2013/09/30/ morre-um-dos-fundadores-da-faculdade-de-servico-social-padrejaime-snoek/ (site visitado em 23/08/2018). Cf. também:

http:/ / www.provinciadorio.org.br/webtv/ exibir/19/Sintonia-Redentorista-no-12---Pe-Jaime-Snoek-CSsRHolandes-de-nascimento-brasileiro-de-coracao.html?p=3([site visitado em 23/08/2018) 
Atas do Conselho Superior da Universidade Federal de Juiz de Fora

Atas do Departamento de Ciência da Religião

\section{Documentos do Conselho Federal de Educação}

Carta memorial enviada ao Conselho Federal de Educação (incorporada no Processo no. 10598/80 - currículo curso Ciência das Religiões - reestruturação)

Universidade Federal de Juiz de Fora. Aviso 142 de 07/02/1974

Parecer no.2244/74, Processo 6.930/74

Ofício no. 5245/77 -presidente do CFE de 24/08/1977

ofício 050932/77 do CFE em 23 de Setembro de 1977.

\section{Matérias de Jornal}

OLIVEIRA, Almir. O curso que não existe. In: Diário Mercantil, 16/07/1977, p.02.

O curso que não existe. Diário Mercantil, 16/07/1977, p.02.

O "curso" e seus defensores. Diário Mercantil, 31/07/1977, p.2

JAPYASSU, Hilton. Ciência das Religiões. In: Diário Mercantil, 20/07/1977, p.02

TEIXEIRA, F. “Ciência das Religiões”. 20/07/1977, Diário Mercantil, p.10

Estudante defende curso que UFJF pode extinguir. Diário Mercantil, 13/07/1977, p.04

Diário Mercantil, 27/07/1977, p.05

Padre vê retrocesso na UFJF, Diário Mercantil, 12/07/1977, p.5.

\section{Bibliografia}

CAMURÇA, Marcelo. Ciências sociais e ciências da religião. São Paulo: Paulinas, 2008.

GROSS, Eduardo. A ciência da religião no Brasil: teses sobre sua constituição e seus desafios. In OLIVEIRA, K. L.; REBLIN, I. A.; SCHAPER, V.G.; GROSS, E.; WESTHELLE, V. (Orgs.). Religião, politica, poder e cultura na América Latina São Leopoldo: Escola Superior de Teologia, 2012. p.13-26. 
HUFF, Arnaldo; PORTELLA, Rodrigo. Ciência da Religião: uma proposta a caminho para consensos mínimos. In: Numen, v. 15, n. 2, p. 433-456, 2012. (http:// numen.ufff.emnuvens.com.br/numen/article/viewFile/1659/1454)

MÜLLER, F. M. Introduction to the Science of Religion. London: Longmans, 1893

OLIVEIRA, Lilian Blanck. Formação de docentes para o Ensino Religioso. Perspectivas e impulsos a partir da ética social de Martinho Lutero. 2003. Tese (Doutorado) - Faculdades EST, São Leopoldo, 2003. Disponível em: $<$ http:// www3.est.edu.br/biblioteca/btd/Textos/Doutor/Oliveira_lb_td35.pdf $>$. Acesso em: 08 out. 2016.

RICOEUR, P. "Hermenêutica dos símbolos e reflexão filosófica”. In: O conflito das interpretações. Trad. Hilton Japiassu. Rio de Janeiro: Imago, 1978. Pp.242-265.

RICOEUR, Paul. A simbólica do mal. Lisboa: edições 70. 2013

SMART, Ninian. The Phenomenon of Religion, London: Macmillan, 1973.

RICOEUR, P. Phenomenology and the social sciences. In: KOREBAUM, M. (Org.). Annals of Phenomenological Sociology, 2. Fairborn, Ohio: Wright State University, 1977b.

SNOEK, Jaime. Ensaio de ética sexual. São Paulo: Paulinas, 1981. set.1967, p.792-803. Disponível em:http://www.diversidadesexual.com.br/wpcontent/ uploads/2013/04//aime-Snoek-art-1967.pdf (site visitado em 23/08/2018)

TILLICH, Paul. Dynamics of Faith. New York: Harper \& Row, 1957.

TEIXEIRA, F. O processo de gênese da(s) Ciência(s) da religião na UFJF. In: Numen, vol.15, no.2, p.537-550, 2013.

WACH, J. Introduction to the History of Religions. New York: Collier Macmillam, 1988. 
Aspectos históricos e epistemológicos da Ciência da Religião no Brasil 
Anexo 1 -Parecer de 1968no qual N. Sucupira sugere a criação de um Depto. de Ciências da Religião
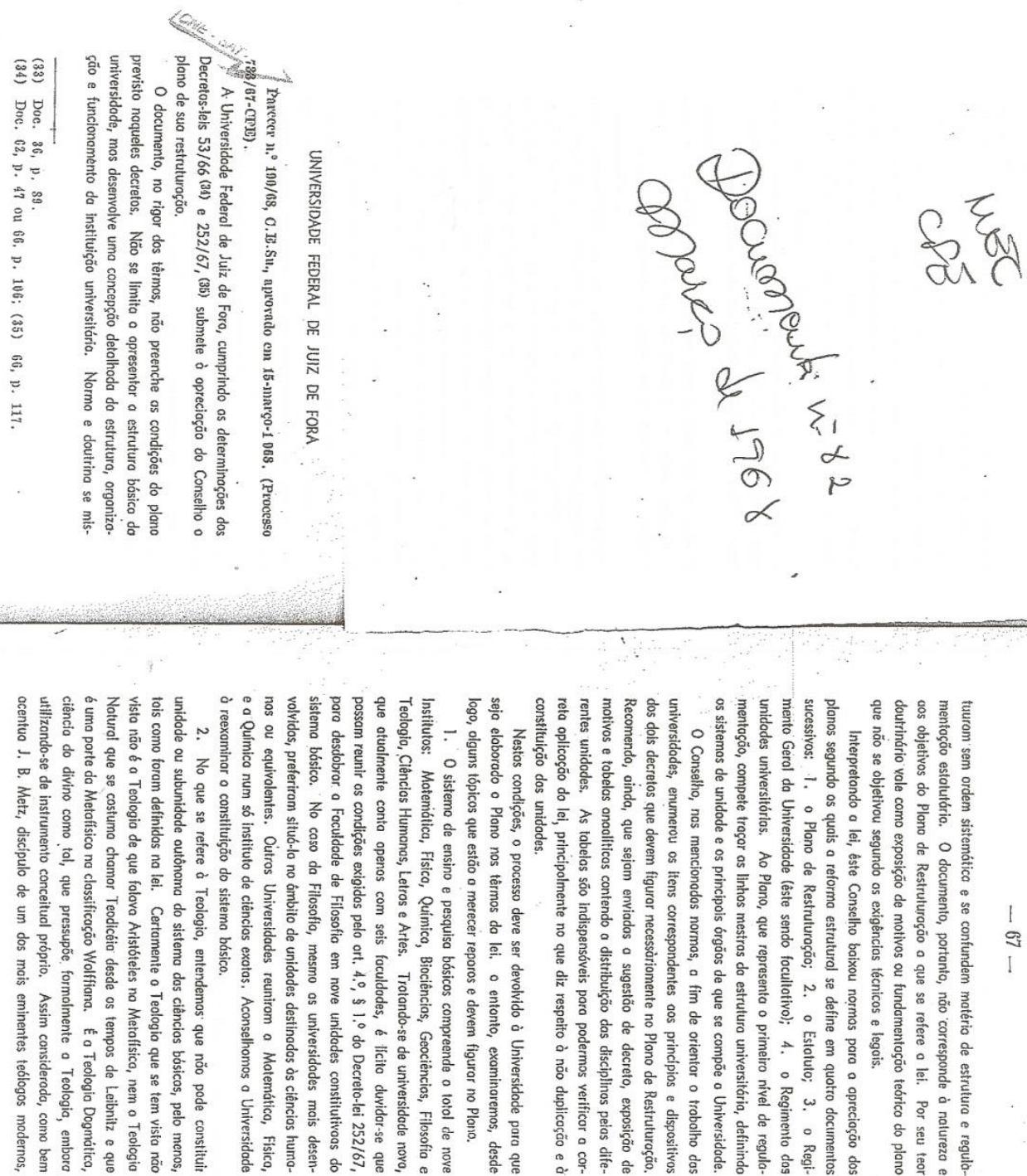

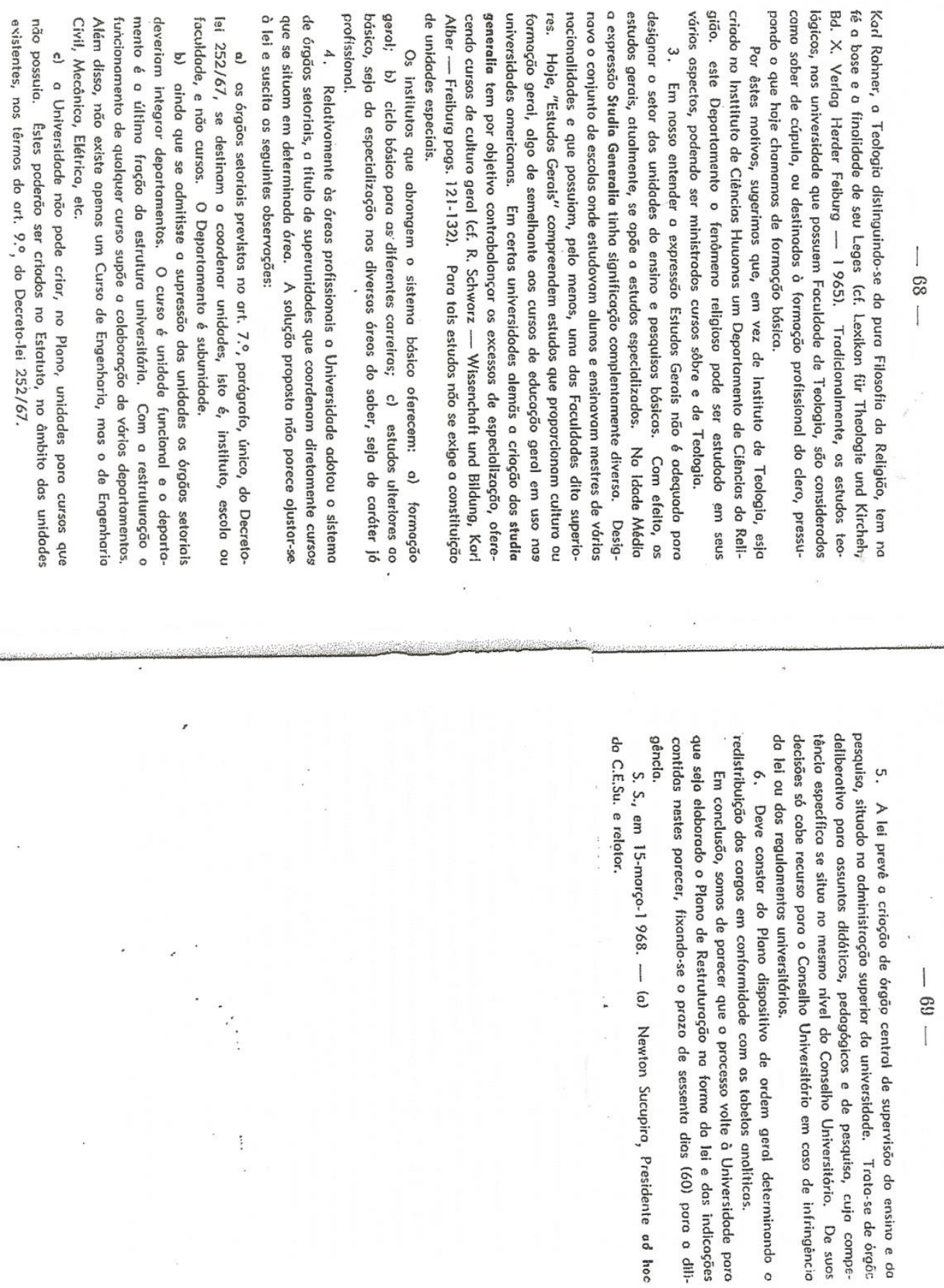
Aspectos históricos e epistemológicos da Ciência da Religião no Brasil 
Anexo2 Parecer sobre diretrizes curriculares para licenciatura em C. das Religiões

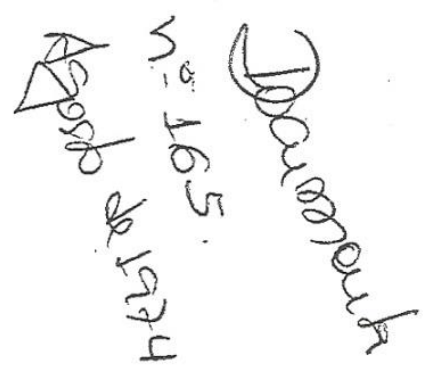

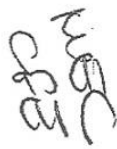
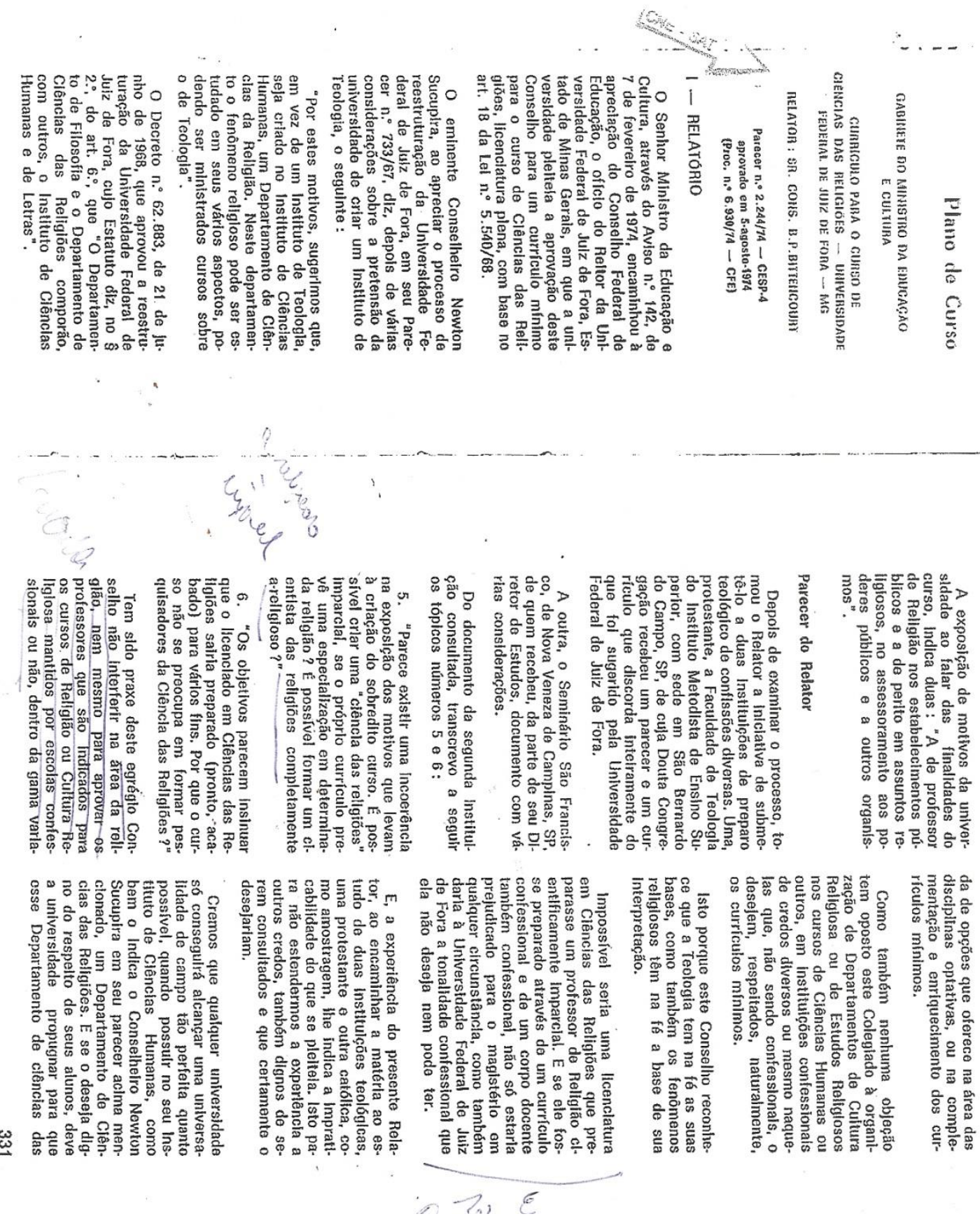
Aspectos históricos e epistemológicos da Ciência da Religião no Brasil
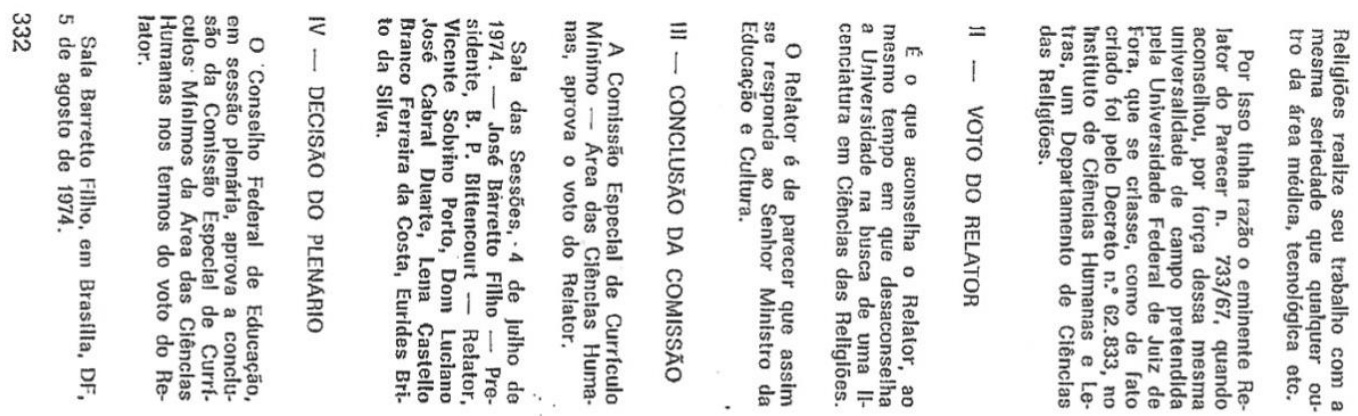
Aspectos históricos e epistemológicos da Ciência da Religião no Brasil

Anexo 3 - Informações sobre o curso 


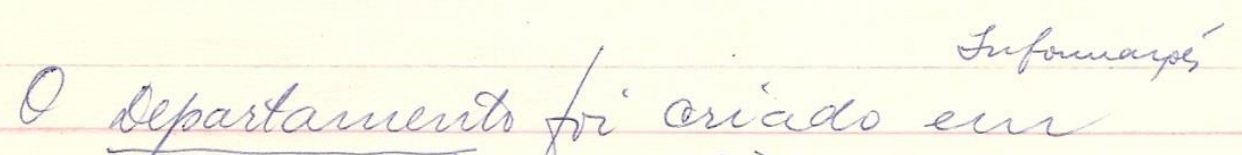
22 de out. de 1921 Realufar do CEPE $140 / 21$.

Oriayai do Ourao hela Univeraidade, apos

negada aprovarad do Ourrículo Minimio pelo corretho Sederal, evir pareus Grue unatra gre o Relatur nod ohegur a entender a solicitacal feita:

Resolugar 35/25 do CEPE (Bocetin 167 - 2ur. 1905 Resoluat $32 /$ Is do Conau:
Poletin 166 .

\section{Vectibulares.}

en 1976: 10 vagas 13 carididates

$$
\begin{aligned}
& \text { Explicayas: hor falta de informaip, } \\
& \text { tres alunis que derefavam fayer } \\
& \text { - Cuso al Cieñia da Religiss } \\
& \text { insueveran te en Tiloosfia, } \\
& \text { uas ertai seguindo as aulas } \\
& \text { do Ouno, }
\end{aligned}
$$

Nosra ex-alma Frangiska Rebhein fay con sucesao o ncestrado de Teologia na PUC-Rio

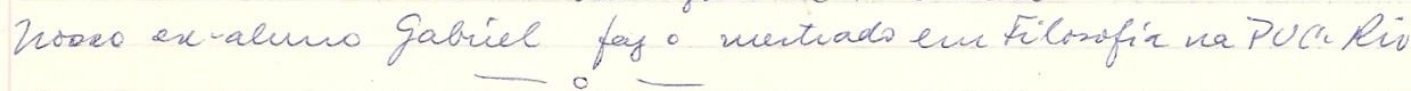

- En andanent o Presso relatio as Colpiado do Cuno.

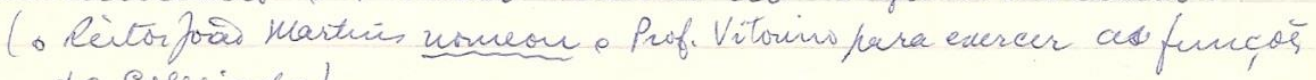
do Colegiado)

Anexo 4 - Carta de solicitação de apoio da CNBB 

Rio do Janeiro - GB.

Revmo. Sr.

Padre Jaime Snoek CSSR

Caixa Postal, 641

36100 - JUIZ DE FORA - MG

of

Recebi e agradeço sua volumosa e apreciada correspondên cia de 18 deste mês. Que bom que sua viagem e seu regresso decor reu sem anormalidades?

Procurei ler e entender o caso do Curso de Ciência das Religiões, inclusive para ver se existe algo a fazer; se for o ca so, voltarei a comunicar-me com o Sr.

Receba minhas atenciosas saudações, com que sou

in caritate Christi

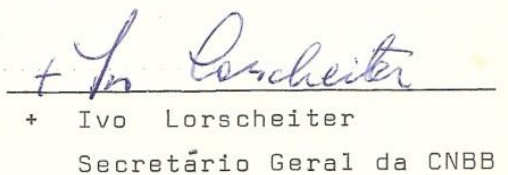

I L /ma 
Anexo 5. Relato de reunião de J. Snoek com D. Geraldo

TORICOS DA ITIFA CONVERSA COH. D.GERTIDO aOs 28.04.1977
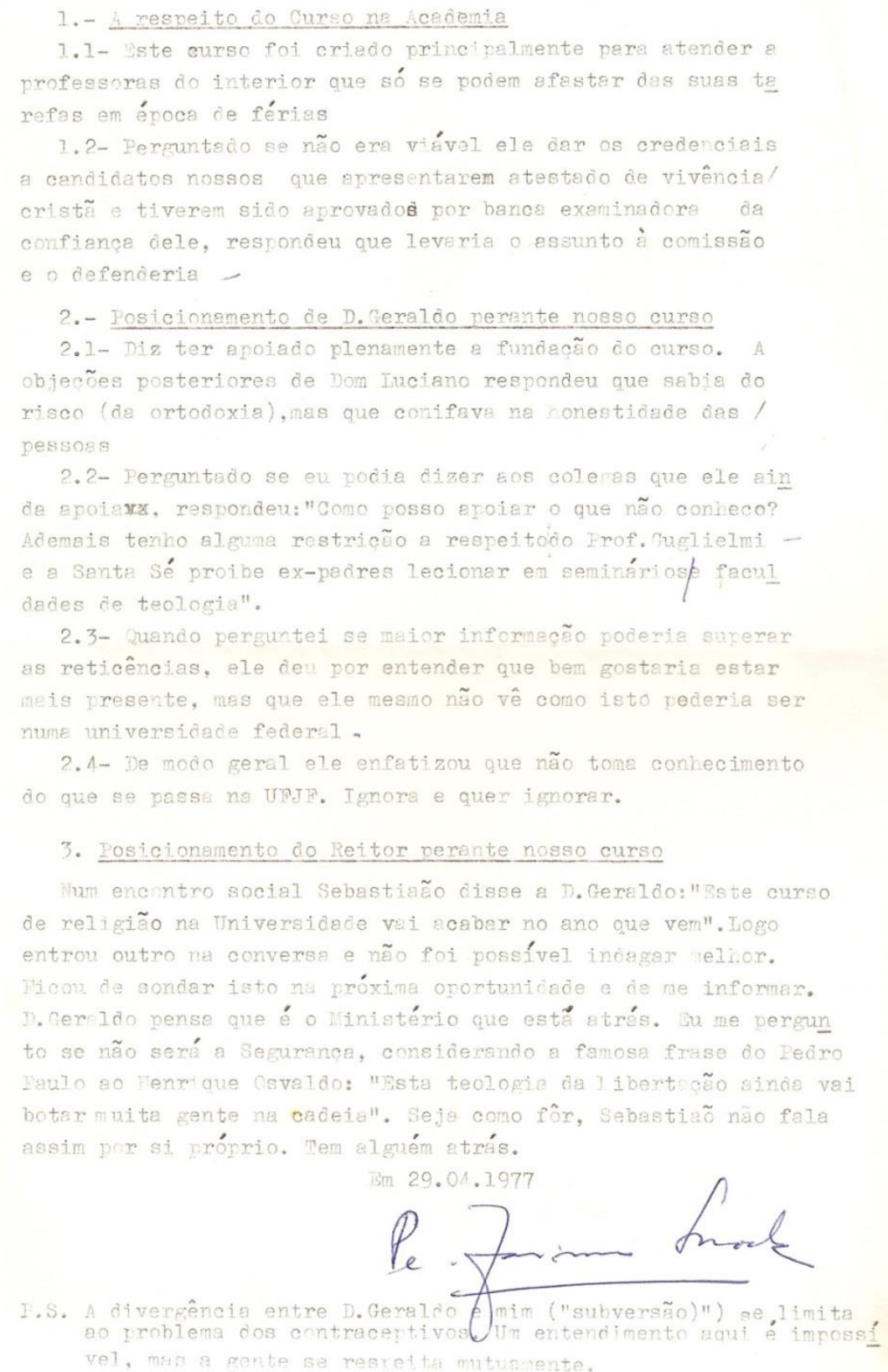
Aspectos históricos e epistemológicos da Ciência da Religião no Brasil

Anexo 6 - Relato da conversa de J. Snoek com Reitor da UFJF Sebastião Paiva 
commicuei aue havia uma inquieteção no meio do pessoal do urso de Ciência das religioes diante de afimacões dele de nẽo abrir mais vestibular pare este curso.

ão tenhe neje contre furso do Sr. (sio). Antes pelo contrário. s tom ciuas coisas: 10 - o curso não foi reconhecido, e eu sou , ́lu rizg o curso prepara:

$$
\text { Responó: }
$$

ad In Como seria illepal se a comissão do contT, conposta de Cilson Salonão e laulo Silveira aprvou sue implantacto? o Sr. já falou con Eaulo Nilveira a este resveito.? (disse que não, que ñ folou com ninguem

lém do mais: pode-se cuirar do reconhecimento, e já estamos trabalhancio nisso

ad $2^{m}$ : o fato de não meparar, pars deteminada profissão, ño ver abolut mente ao caso. Ha cois pareceres de Sucunir:

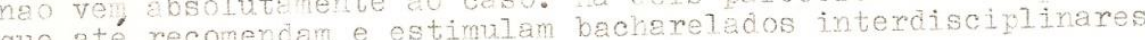
sem determinada profissão.

†I não teve resposta.

perguntei ainda: se alguen tinha dado instmẽos. ouase jurou que não.

Serǵ nesmo?

\section{Sugestões}

Tha ver oue foi levantada a questão da legalicade, crejo que se

deve levar adiante manto antes o projeto de legaíizacão.

Iar isto:

- devemos aprimorar logo o entevrojeto, submetê-lo ao Depto

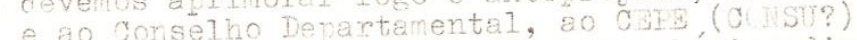

- manter contato con Faulo Silveira; lá impedémento legal

pars ebertura de vestibuiqur?

- pedir ajuda ao VEITURA, que não deixa de ser peca importante

- abordar conselheiros do CFE:

Fruén - Vasconcellos

Ventura - Abu- Tekr

? - cDowe1]

- Dom Tuciano (Dom Geraldo? Dom Lame? Don Brandão?)

- Sucupira (Arcélio?)

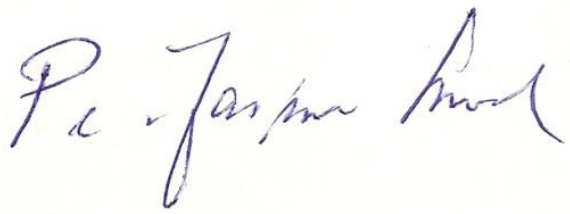

\section{2}




\title{
Anexos 7 - Manifestações dos discentes
}

\author{
C I ENCIA DAS REIIGIOES

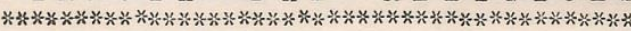 \\ Curso livre
}

Religião e Religiosidade, depois de um período de hibemação, estão de novo na crista da onda. "Jesus People", "Children of God", "Hare Krishna", cediłação transcenden tal, "Hatta Yoga", pentecostalismo, jomada, Umbanda, Conselho Mundial de Igrejas, Cursi Ihos, Nairobi, Enaús, Taizé, são apenas algumas entre muitas manifestações desta realida de.

A ciência tem algo a dizer sobre isso? Sem dúvida. O Curso de Ciência das Religiões está tentando ajudar nesta reflexão. Num curso de aproximadamente tres anos, com uma média de cinco ou seis disciplinas por período, analisa a religiosidade sobre todos' os seus aspectos. Um primeiro conjunto de disciplinas $v i \dot{B a}$ elucidar a religiosidade como tal e as religiões em geral. São as seguintes: Sociologia, Psicologia da Religião, Socio logia da Religião, Estudo Comparado das Religiões, Filosofia dai Religic̃og Ética. Um outro conjunto aprofunda o Cristianismo: Introdução ao Mundo Bíblico, História do Cristianismo, Antropologia Bíblica, Cristologia Bíblica, Eclesiologia Bíblica, Escatologia Bí blica, Cosmovisão Cristã, Cristologia Sistemática, Eclesiologia Sistemática, Elementos ' de Moral Cristã.

No fim do curso, se quiser obter o certificado de bacharel, você irá elaborar' uma tese sob orientação de um dos professores do curso.

Você poderá simultaneamente seguir disciplinas de outros cursos. 0 màis afim é - de Filosofia, que tem inclusive sua programação sintonizada com o de Ciência das Religiões. Isto facilitará depois a obtenção de outro diploma.

E bom saber que o Curso de Ciência das Religiões é um chamado curso livre, sob a responsabilidade exclusiva da UFJF e o certificado de sua conclusão não poderá ser registrado no MEC. Seu valor é outro: vale o que o curso vale.

Una vez que você tiver conseguido transpor o limiar de acesso à Universidade, não deixe de procurar o Departamento de Ciência das Religiões e/ou a Coordenação do Curso para maiores esclarecimentos. Contamos con você.

Feliz vestibular! Até breve!

Departamento de Ciência das Religiões

Publicação do Diret'́rio Acadêmico Tristão de Athaíde ICHL 
Cono é do conhecimento de todos, foi negado o pedido de afixamento de currículo mínimo para o funcionamento de um curso de Ciências das Religiões na U.F.J.F.. Antes mesmo de ser publi cado oficialmente a decisáo do C.F.E. e, já sabedor dos rumos que tomava o processo o D.C.E. munido do parecer/ do relator, enviou a Ministro da Edu caça oficio estranhando as visiveis contradicões existentes em tal pare cer.

Acreditamos que sendo endereçado a um Ministro da Educaçäo e que os principios mais réles, ditam por res postas, aguardamola. E a resposta nos foi dada: Confirmando mais uma vez a "importancia" que é dada ao universitário vindo ela sob forma de decreto, confirmando o absurdo parecer do CFE. Achamos que hora se faz, de dar às instituiçoes, que ten à mäo o poder de munir nossos executivos de informações, pessoas verdadeiramente ca pazes para isso.

Mais uma vez lamentamos e faze mos público nosso protesto, mesmo que este seja considerado "coisa de estudante".

\section{Fundamental}
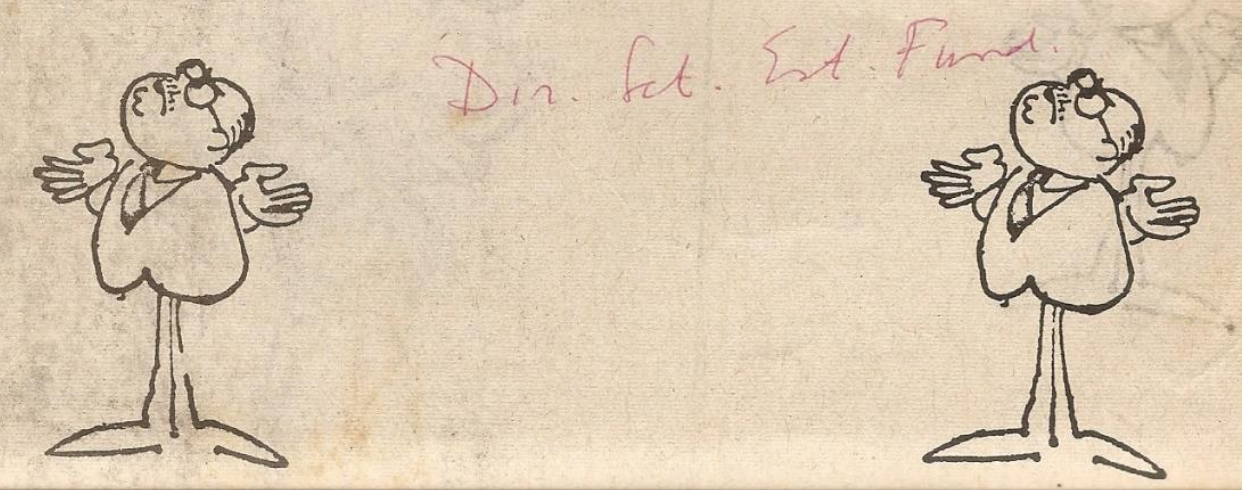


\section{Anexo 8 - Repercussão na imprensa local}

\section{Ciência das religiões}

Quero manifestar minha preacupação diante da possibilidade da eliminacäo dio curso de Ciência das Religiöes da Universidade Federal de Juiz de Fora. E' lamentável que uma Universidade federal não tenha autonomia para respeitar $e$ compreender a dimensão e importancia de um curso que é altamente valorizado na Europa. Um estudo adequado do fenomeno humano riäo pode dispensar a análise científica do homo religiosus. A religiosidiade é um fenômeno universal e um đos elementos constitutivos da cultura. Não vivemos tempos promissores em relarão às Etiencias Humanas, mas a eliminaçäo arbitrária deste curso de Ciência das Religiöes seria como que fechar as portas à promoção humana, à ciência e ao futuro, como que a constatação empirica dó encolhimento do campo de consciência de nossos líderes. Contamos com a compreensão e o apoio dos diversos setores de nossa cidade e do Brasil em nossa luta pela sobrevivência. Contamos com a participação dos intelectuais, dos artistas, dos professores e da Igreja para que o obscurantismo não seja estabelecido. Faustino Luiz Couto Teixeira Juiz de Fora (MG). 


\section{Anexo 9 - Repercussão na imprensa local}

\section{Ciência das Religiōes H.tton Japyassu}

A Universidade de Juiz de Fora estava se parabéns. Porque havia ousado superar o velho ranço positivis ta, com seus preconceitos obscuran tistas, e instaurado, em seu seio, curso de Clências das Religiōes. Fato pioneiro no Brasil. E único. Diq to prande envergadura de inteligência de quem lutou por tal implar. gência de quar de ser um curso que. taça. Apelidade dos que năo pensam, na mentalidas do saber, dos que säo dos burocratas do saber, filos que sấ comandados por uma filosofia mercantilista e pragmatista, dos que re duzem o Saber a uma ideologia po. cuniária do "status" que possa con ferir a formação universitária, dos que negam o Saber em proveito do poder, não serve pará nada. Ora, é poder, nate porque não "serve" para justamente ele serve para tudo. Pelo mada querve para impedir a ignomenos, serve para formacão bitolada. nância, impedir a formána bitolada. estreita, miope e estrabica, sem envergadura intelectual, sem horizonte de espirtto. Serve ainda para conver. ter esse agiomerado de escolas técnicas, que chamamos de Faculdades numa Universidade digna desse no. me.

A Universidade não pode ser re. Autic a servico público especiaduzida a um "formar" certos funcions. lizado para ciormar certos funcionarios indispensaveis ao bom andamento da administraçáo e colocá-los a serviço exclusivo do mercado produtivo. A Universidade não é um aglomerado de escolas profissionais des. tinadas a produzir em série mão-de tiala qualificada: Porque nāo é urn meio, uma indústria nacionalizade meio, a fabricar analfabetos. destinada a ficando o Saber, trancendentes, ficando Cultura e o pensam como se fossem um luxo inteiramente dispensável. Ora, só mesmo a iạ. norância ou a má-fé podem identiflcar Clências das Religiōes com Teologia. A Universidade deveria ser, em relaçăo ao Estado, o poder cultuEssa autonomia poderia ser com. ral. enssa civilizacão, à da parada, indiciáśl 0 Estado remunera função judisián tica, e nåo para o serviço do Estado.
Assim, a funçăo da Universidade é a de manter a cultura pelo ensino e a de promover a pesquisa. Sua tare fa é a de inventar a cultura no seio de um mundo que se desfaz a se refaz $E$ é inventando a cultura que refaz. E a Universidade assegura. na Naçăo. uma funcăo essencial à honra do Es. tado. E é por isso que o destino da alta cultura nāo pode ficar entreque aos caprichos alternados dos tecnocratas orqanizadores e dos demago aos. A Universidade não é um centro de formacāo acelerada para as trotegorias de técnicos de que o Pais categorias de técnicos de ques pais lugar onde se preparam homens cepazes, sem dúvida, de ocupar este ot: aquele empreşo especializado. mas caracterizados também fior uma ampla compreensao da cultura em devir. O sentido dos conjuntos, a facu'. dade de invencâo, a consciência das implicacöes do conhecimento, n res. peito pelo humano, são qualidades peito pelóveis a todo homem realindispensaveis a thdo home treinedo ou adestrado em oficinas do saber.

E claro que a Universidade pode - deve contribuir para a formação profissional de certas categorias so ciais. Mais esta nāo é sua função exclusiva tampouco sua destinação principal. Enquanto se vir na Universidade um depósito central da culversidade un depósito central da cultura, tendo por funçăo distrilsuir ses cỏes aos educandos, pela pedagogia da transmissão ou do inculcamento. tendo em vista adequar, máo somente o conteúdo do ensino, mas também sua forma, às palavras de ordem do mercado de trabalho, do rendimento e da eficácia no dominio da acão, näo haverá lugar para um curso do tipo "Ciència das neligióes". Ele so so "Ciencia das Religioes "Ele só se justifica numa Universitas scientiarum tendo por missấo encarnar a "teoria", vale dizer, a força e o poder do conhecimento e da reflexão, desvinculados, o mais. possivel, das aderências politicas, administrativas e ideológicas, hem como dos interesses de certos crupos de proprietá. rios patentearios do saber. Ora, se a Universidad́n năo é uma penitenciária central da cultura, pergunta-se: em nome de quê faz-se uma cruzada pretensamonte laica, na realidade, verdadeiramente "religiosa" (pois A serviço de um culto inconfessado), con. tra a introdução de um curso que so faz orqulhar a Universidade cue a possui? Por acaso pretende-se domesticar a inteligência dos educandos, endisciplinála (no sentido de dos, endiscipliná-la (no sentido de
enquadrá-la segundo as exiçências de preconceitos relativos a certas atividades profissionais a serem exercidas? Seria lamentável que a inteligência dos homens de Juiz de Fora viesse, de vez, a esclerosar-se; que viesse, de vez, a esclerosar-se; que sua visao se tornasse miope; que sua mentalidade fosse tão provinciana e pequena para ter medo de um curso que só vem ampliar os horizontes mentaiș. enriquecer a inteli. gência, promover a cultura, robuste. cer a capacidade de pensar e de criar. Antecipadamente, tránsmitoIhe, e a todos os espíitos clarividentes déssa cidade que tanto estimo minhas condolências, caso esse mo. minhas condoléncias. caso assassinato cultural venha a ser cometido pela cegueira dos que tểm medo de defrontar-se com o pode da cultura e de pensamento. Estou certo de que a inteligéncla vencerá o obscurantismo. De que a razão vencerá a paixāo. De que a verda. de vencerá o medo. De que a ousa dia triunfará contra as forças retrógradas do pensamento. $E$ que a Unigradas do pensamento. E que a Universidade do Juiz de Fora procure sempre ser o lugar proprio da comunicade das disciplinas e da comunidade dos "doutos", onde a ignorâncla nấo se converta em virtude, onde a mediocridade não seja promovida em saber.

Enfim; o meu apoio a todos que estăo empenhados, não em "saivar" um curso em vista de seus interes. ses mas um curso que digulifica a inteligência e magnifica a cultura de um povo, conferindo real estatude um povo, conferindo Universidade to de Universidade 


\section{Anexo 10 - Repercussão na imprensa local}

\section{O Curso que não existe \\ Aimir cie Oliveira}

0 Magnifico Reitor da UFJF pós $n$ dédo no tumor. O chamado. "Curso de Ciência das Re ligiòes", que em hora infeliz se criou na Universidade, está so o o exame de sua Magnificência. Há muito que os seus criadores e defensores estão pelejando ñana que isso perdure na UFJF. Q uma excrescência. Não tem razáo de ser. Nenhuma Universidade no Brasil tem essa coisa. 0 Conselho Federal de Educa. cáo năo o aprovou. Mais do que isto: recusou-lhe aprovação. Não há, um currículo mínimo que, de acordo com a lei, possa servir-lhe de base. Mas, em Juiz ie Fora, para atender a certos interesses pessoais e de um grupo irrisório, meteu-se na estrutura umiversitária um Departamento de Ciências das Religiões, crioutse um Curso de Ciência das Religiōes. O Curso não logrou aprovação do CFE. O Departamento continua enquistado na estrutura do ICHL, constituindo-se num órgẩo a mais, com problemas a mais, com re. sultados:positivos a menos. Fornece disciplinas para outros cursos, à guisa de complementaçào de créditos. E há uma disciplina que já está tristemente famosa pelo descritério que preside a sua ministraçăo:. "Introdução ao Mundo Bíblico". Matéria bonita, sem dúvida; que seria de utilidade para melhorar a cultura dos estudantes. Mas, 0 apelido que lhe deram é: "Quá-quá-quá". Ministrada à noite, fora do recinto da Universidade, é uma espécie de panamá. Uma enxurrada de estudantes se matricula nela, porque ali "é mole": nada de cha mada; todo mundo passa ao final e obtém mais uns créditos, na base da moleza. Não sei se há outros exemplos. 0 certo é que a Universidde não pode diplomar ninguém em "Ciência das Re. ligiổes". Quando se cuidou de tal "Curso" no Conselho Universitário onde percebi uma forte pressão grupal, indaguei pra que se queria aquilo, que espécie de profissional se pretendia formar. Não me deram uma resposta satisfatória. Mas. o "Curso" foi criado. E o CFE não o aprovou. $\mathrm{E} \mathrm{el}_{\mathrm{e}}$ continua. recebendo matrículas. Ainda não houve quem tivesse coragem 'e pôr fim a essa farsa: um Curso que não pode diplo. mar ninguém. que não dá "status" profissional a ninguém, que não serve pra nada, senão para criar problemas para a Universidade

Foi bom que o Magnifico Reitor tomasse a si e a sério a solução do problema. Sei que está se movimentando um grupo de interessados na manutenção do "Curso Fantasma", 0 argumento é o de que a Universidade deve ter como cúpula do seu ensino o da Teologia. Mas, isto é outra coisa. Além do mais. o Estado brasileiro, a que pertence a Universidade, é leigo por força da Constituição
Então, há que perguntar: que Teologia se ensinará na Univer. sidade estatai? A cristã (católica. ortodoxa, ou protestante?), a budista, a xintoista, a muçulmana, a taoista, a brahmânica, a judaíca, a confuđiana? Todas elas, para ressalvar a neutralidade do Estado em face das religiốes? E onde encontrar os professores de todas elas? Arranjar um teólogo, que o seja de verdade, já é tão difícil no meio católico, neste Brasil de católicos, quantó mais dez teólogos. Diga-se de passagem que esa denominaçẫo "Cursb de Ciência das Religiōes" foi um arranjo para evitar a cienominação "Curso de Teologia", que os inventores da coisa não tiveram coragem de propor e sustentar. Ou porque tivessem receio de ser tido como inconstitucional, ou porque se sentissem desapetrechados para ministrálo com a seriedade que ele exige.

Penso que, nesta hora em que se está revendo a estrutu. ra da UFJF, está a oportuniđa. de para espremer o tumor e extirpá-lo. Há algumas outras razões ,que não vâo aqui. agora. para justificar a extinção do "Curso" e do Departamento de Ciência das Religiôes. O processo, que foi ao CFE e de lá voltou com a formal desaprovação do "Curso" tem as legais, que bastam. As de ordem interna. o Magnífico Reitor que as investigue, se quiser. E as encontrará. 


\title{
Anexo 11. Comissão de apoio à continuidade do curso
}

\author{
Excelentíssimu(a) Senhor(a),
}

Face a propaladas notícias do possível fechamento do Ourso de Ciên cia das Religiões na UFJF, uma comissão, formada sobretudo de Professores, ex-Profes sores, Alunos e Ex-alunos que, de perto, seguem o benefício que esse Curso presta a essa comunidade, vem à presença de V.S. no sentido de solicitar seu apoio para a pre servação desse Curso de Ciência das Religiões pelas autoridades competentes.

Para que V.S. possa sentir-se mais esclarecido a respeito da impor tância do Curso e assim sentir-se mais motivado a unir-se ao apelo da comissão tomamos a liberdade de the fomecer algumas informações fundamentais:

1. Teoricamente o Curso de Ciência das Religiões analisa em nível científico o fenômeno da religiosidade que é um dos elementos constitutivos de nossa cultura. Nossa Universidade seria incompleta se não incluiese no rol de seus cursos a auto-interpretação filosófica e religiosa do homem, como já o fazen as grandes Uní versidades estrangeiras.

2. O Brasil sempre reconheceu na religião o manancial principal de sua cultura e a confirmar tal asserção temos sucessivos e coerentes pronuncianentos de nossos govemos.

3. O Ensino religioso nas escolas públicas e oficiais exige competência dos coordenadores e ministradores desse ensino tão delicado. O Curso de ciên cia das Religiões na UFJF pode colaborar como de fato tem colaborado para a fornação desse pessoal especializado.

4. A estrutura e as linhas básicas do Ourso abertas à análise

fenômeno religioso sem se prender a domínios sectários e confessionais colocam-no den tro de nossa orientação política e demográfica que se caracteriza pela neutralidade e pluralidade confessional.

Funcionando, há dois anos, na UFJF, o Curso de Ciência das Religiões tem, pelos motivos expostos, comprovado a sua utilidade. Pelo que a comissão está consciente de ser válido o apelo pela sua permanência e para tanto conta com a adesão de V.S., com a compreensão e o precioso aval...

Fola Comissão: Maria do Céu Corrêa Mendes

Presidente da Comissão

Dr. Nozart Geraldo Teixeira

Vice-Presidente

Marília de Araújo

Secretária. 


\title{
Anexo 12. Ofício sobre o debate na imprensa
}

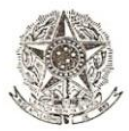 \\ MINISTERIO DA EDUCAC̄ÃO E CULTURA \\ UNIVERSIDADE FEDERAL DE JUIZ DE FORA \\ SETOR DE ESTUDOS FUNDAMENTAIS \\ INSTITUTO DE CIENCIAS HUMANAS E DE LETRAS \\ DEIARTAMENTO DE CIÊTCIA DAS REIIGIÕES
}

Exmo. Sr.

Prof. Sebastião de Almeida Priva

Magnifico Reitor da U.F.J.F.

Magnifico Reitor

Terão chegado, com certeza, ao conhecimento de Vossa Magnificência os artigos recentemente püblicados pelo frofessor Almir de Oliveira no DIÁRIO NERCANTI, órgão da imprensa desta cidade de Juiz de Fora, contendo ataques soezes e aviltantes ao Curso de Ciência das Religiões e ao Departamento do mesmo nome, contendo aleivosias assacadas nominalmente contra um de nossos reconhe cidamente mais ilustres professores.

o Departamento, profundamente atingido pelo ataque inusitado, tomou a medida única que lhe pareceu cabivel, isto é, pediu ao $\mathrm{Sr}$. Diretor do Instituto de Ciencias Humanas e de letras uma providência legral.

O Departamento de Ciência das Religiões se recusa. a aceitar o desafio da polêmica pelas seguintes razões, entre outras:

1. Supõe estar ainda em vigor a Fortaria emanada desta Reitoria, assinada pelo Reitor Frof. João Martins Ribeiro, que proibe a manifestação pública de Irofessores ç̃ om referência a assuntos internos da Universidade, sem autorização do Magnífico Reitor.

2. Considera deprimente para a Universidade tal tipo de polêmica entre lrofessores.

3. Não se julga em condições de descer ao nível em que o fropessor articulista colocou unilateralmente o desafio à polêmica.

Tomamos a liberdade de dirigir-nos a Vossa llagnificência afim de evitar que o nosso silêncio possa ser interpretado como assentimento a qualquer das afirmaçóes do frofessor articulista.

Com os protestos de nossa consideração,

atenciosamente

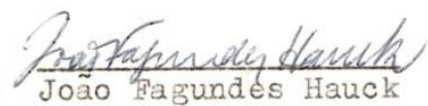

Chefe do Departamento de C. das Religiões

Juiz de fora, 12 de agosto de 1977 


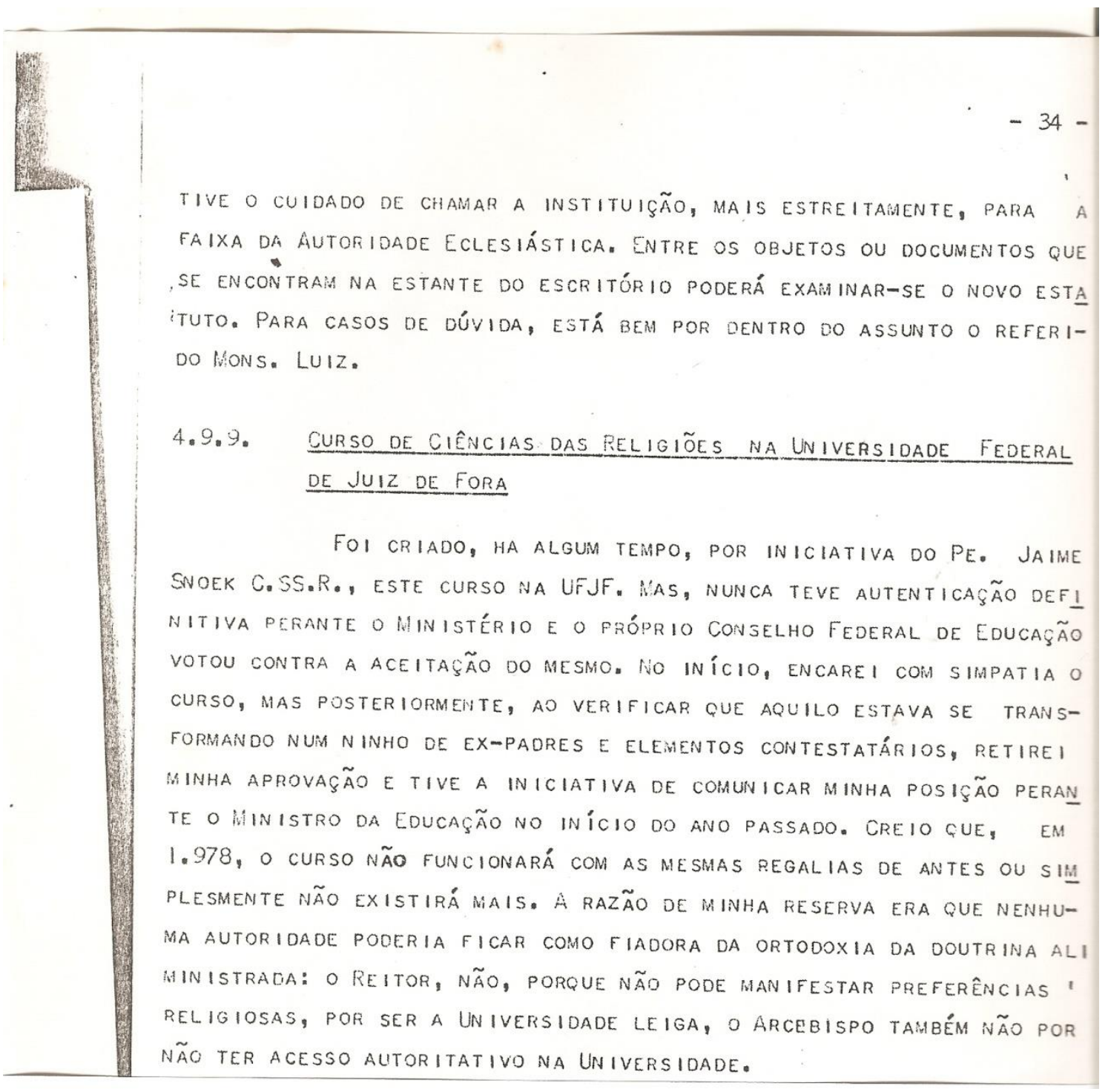


Anexo 14 - Proposta de W. Gruen para metodologia do Ensino Religioso

UNIVERIDADE FEDERAI DE JUIZ DE FORA

\section{METODOLOGIA DO ENSINO REIIGIOSO}

(Um primeiro esboço de conteúdos programáticos)

1. FUNDAMENTOS

1.1 A realidade

1.1.1 Situação religiosa do Brasil

1.1.2 Panorama do ensino religioso na escola brasileira

1.2 Conceitos básicos

1.2.1 Religiosidade, religião, religiões

Ecumenismo

Ateísmo. Agnosticismo.

A. "nova religiosidade"

1.2.2 Fé explícita

20 ENSINO RELIGIOSO ESCOLAR

2.1 A problemática do ensino religioso escolar

2.2 As normas vigentes

2.3 Diversas alternativas

2.3.1 Catequese confessional ou ecumênica

2.3.2 Educação sistemática de religiosidade

2.4. Aprofundamento das alternativas relativamente a

2.4.1 Natureza

2.4 .2 objetivos

2.4 .3 Modelos

2.4.4 Currículos

2.4 .5 conteudos

2.4 .6 Linguagem

2.4.7 Métodos

2.4 .8 Recursos

2.4 .9 Organização

2.4.10 Habilitacão dos docentes

2.4.11 supervisão

2.5 Criterios para uma opcäo entre as diversas alternativas

3 ESTUDO DE ALGUNS PROBIENAS ESPECÍPICOS

inemplos:

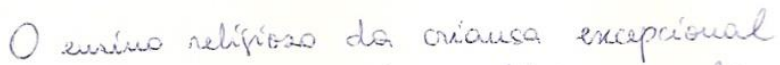

Quvaliacão no enrius nelifiono exdar

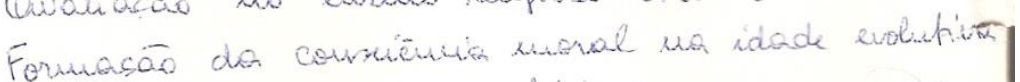

Q Biblia wo evaimo nelifioso

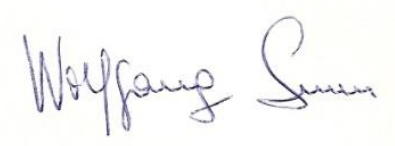

$27.05 \cdot 80$ 